\title{
A Watershed Level Economic Analysis of Cellulosic Biofuel Feedstock Production with Consideration of Water Quality
}

\author{
Jin-Young Moon ${ }^{1}$, Jeffrey Apland ${ }^{2}$, Solomon Folle ${ }^{3} \&$ David Mulla $^{3}$ \\ ${ }^{1}$ Korea Institute for International Economic Policy, Sejong, South Korea \\ ${ }^{2}$ Department of Applied Economics, University of Minnesota, St. Paul, Minnesota, USA \\ ${ }^{3}$ Department of Soil, Water and Climate, University of Minnesota, St. Paul, Minnesota, USA \\ Correspondence: Jeffrey Apland, Department of Applied Economics, University of Minnesota, St. Paul, \\ Minnesota 55108, USA. Tel: 1-612-625-1353. E-mail: japland@umn.edu
}

\author{
Received: February 16, 2016 Accepted: February 28, 2016 Online Published: May 26, 2016 \\ doi:10.5539/sar.v5n3p56 \\ URL: http://dx.doi.org/10.5539/sar.v5n3p56
}

\begin{abstract}
National policy supports the production of renewable energy from cellulosic feedstocks such as corn stover and switchgrass. These feedstocks have contrasting impacts on water quality. In this study, the regional supply response for cellulosic biofuel from these two feedstocks is estimated for the Le Sueur Watershed in South-Central Minnesota. The impacts of the resulting agricultural production activities on water quality in this northern corn belt watershed are also estimated. The Le Sueur River is a tributary of the Minnesota River, which in turn feeds into the Mississippi. The analysis is conducted with a multi-region, endogenous supply, mathematical programming model of the agriculture sector in the watershed. A unique aspect of the analysis is the spatial detail used in the production model. Results from a previous simulation analysis conducted with the Soil Water Assessment Tool (SWAT) model are used in the economic model to simulate the effects of the feedstock supply response on water quality in the Le Sueur. Sediment and nutrient losses from corn stover production make switchgrass more promising on environmental grounds, but the relatively high cost of production causes switchgrass to cover only a small part of crop land if farmers have unrestricted choice about how to supply cellulosic feedstocks.
\end{abstract}

Keywords: biofuel, cellulosic feedstock, mathematical programming sector models, water quality, watershed

\section{Introduction}

Interest in alternative energy sources has been growing for a variety of reasons, including volatile oil prices, recognition of the harmful effects of greenhouse gases and national security concerns over oil imports from politically unstable regions (Hill et al., 2009). Recent policy initiatives reflect this concern. For example, the Energy Security and Independence Act of 2007 sets a goal of producing 36 billion gallons of ethanol and other renewable biofuels by 2022. The Act sets a cap of 15 billion gallons of ethanol produced with corn grain, requiring the remaining production to come from advanced renewable biofuels such as cellulosic ethanol. There is a large potential for the U.S. agricultural sector to provide biomass (Hoekman, 2009). However, trade-offs related to the environment, economic cost and food security are major concerns (Khanna et al., 2009).

Cellulosic feedstocks are composed of cellulose, hemicellulose and lignin, which comprise a significant proportion of the biomass of plants. The cellulose and hemicellulose can be converted into ethanol by chemical or biochemical reactions and lignin can be used through combustion or gasification in order to produce steam and electricity (Huang et al., 2009). Various cellulosic feedstocks are being considered for producing cellulosic ethanol, including corn stover, wheat straw, switchgrass and woodchips. Though currently most ethanol refineries use corn grain as a feedstock, cellulosic ethanol has advantages over grain ethanol. Using corn grain for ethanol creates direct competition between fuel and food production (Runge \& Senauer, 2007). Some sources of cellulosic feedstock, such as corn stover, are co-products of grain production. And cellulosic ethanol has been estimated to reduce greenhouse gases more than corn ethanol. Farrell et al. (2006) predict that corn ethanol would reduce greenhouse gas (GHG) emissions by about $13 \%$ relative to gasoline. Hill et al. (2009) predict that cellulosic ethanol production would lead to lower GHG emissions than corn ethanol or gasoline. Their results indicate that corn ethanol has more life-cycle GHG emissions than gasoline when emissions resulting from changes in land use are included and corn ethanol process heat is from natural gas or coal. Fargione et al. (2008) 
find that converting grassland or abandoned crop land in the U.S. to corn-ethanol production releases 48 to 93 times more $\mathrm{CO}_{2}$ than the annual greenhouse gas reductions these biofuels provide by displacing fossil fuels. They find that biofuels from perennials grown on marginal or abandoned cropland can offer immediate and sustained environmental benefits. Schmer et al. (2008) estimate that switchgrass ethanol emits $94 \%$ less GHG than gasoline.

Using corn stover for cellulosic ethanol production could lead to changes in crop rotations and the composition of crop production. Intensive corn production requires heavy fertilizer use, which is increased further when stover is removed and the nutrients lost in the residue must be replaced. Thus, absent any offsetting measures to protect water quality, the use of stover as a biofuel feedstock can be expected to have negative impacts on water resources. Energy crops such as switchgrass can be used as cellulosic feedstocks and have environmental benefits relative to corn production, particularly when the corn stover is harvested (Folle, 2010). Switchgrass is a warm season grass native to North America and grows well under a wide range of climate conditions (Vogel, 1996). It is a perennial grass that develops a deep and dense root system, promoting soil stability, increasing infiltration and reducing runoff (Redfearn et al., 1997; Woolsey, 1992). Once established, a switchgrass stand can persist for many years under the right conditions, which reduces maintenance costs relative to conventional row crops (Tiffany et al., 2006). Switchgrass could be planted on degraded and abandoned crop land for use as a biofuel feedstock, reducing ecosystem destruction and greenhouse gas emissions (Fargione et al., 2008).

This paper focuses on the economic and environmental impacts associated with the production of two cellulosic feedstocks: corn stover and switchgrass. Using a multi-region, mathematical programming model of the agriculture sector in the Le Sueur Watershed in South-Central Minnesota (see map in Figure 1), details of the feedstock supply response at a centrally located biofuels plant are explored. By using environmental parameters from a biophysical simulation analysis of the watershed, the economic model is able to estimate the impacts on water quality of the producer response that accompanies expanded feedstock supply. Based on a calibrated and validated biophysical simulation analysis by Folle (2010) using the Soil and Water Assessment Tool (SWAT), a high level of spatial detail on crop production, soil loss and nutrient loads is supported with parameter estimates for 4,178 homogeneous crop land areas or hydrologic response units (HRU's). By capturing a spatial market equilibrium within the watershed, the model is able to estimate the impacts of expanding feedstock demand on the spatial distribution of crop production and production practices. The biophysical simulation results allow estimates to be made of the changes in sediment losses, and nitrogen and phosphorus loads resulting from cellulosic feedstock production.

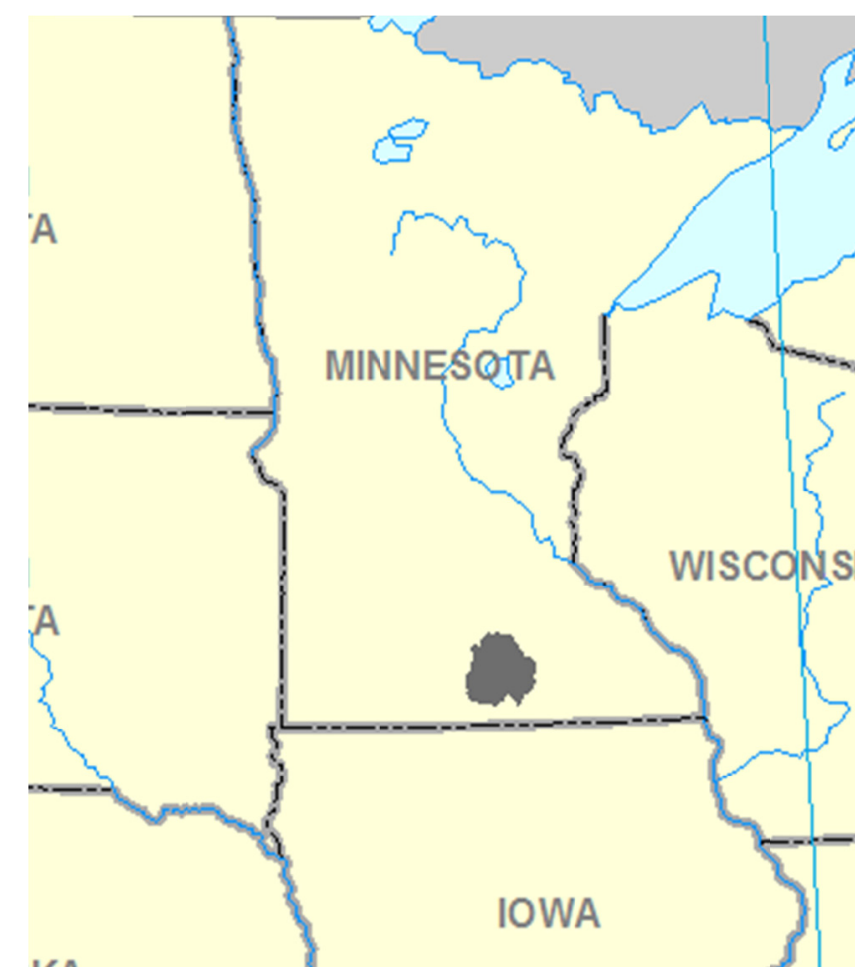

Figure 1. Map showing the geographic location of the Le Sueur Watershed (shaded area) 


\section{Background}

A wide range of research has been conducted on the production economics of cellulosic feedstock production. Petrolia (2008) compares two collection technologies, round bales and square bales, to derive an estimate of corn stover delivered cost for a proposed biomass-to-ethanol conversion facility located in southern Minnesota. The paper assumes that all baled stover is staged at the field edge then hauled to storage by semi-trucks. The study does not consider alternative stover harvest rates and assumes average corn grain and stover yields for each county within the study region. Brechbill and Tyner (2008) compute corn stover and switchgrass production costs and estimate biomass supply curves for three Indiana coal-fired electric utilities from county-level production data. They estimate biomass production cost by considering whether equipment is owned or custom hired, what baling options are used, the size of the farm, and the transport distance. Payments for extended storage and a profit premium are introduced to compensate producers for providing biomass to plant. They found the total cost per ton for a $48 \mathrm{~km}$ (30 mile) radius around the plant ranged between $\$ 39$ and $\$ 46$ for corn stover and $\$ 57$ and $\$ 63$ for switchgrass.

In a national level study, Gallagher et al. (2003) examine biomass supply from crop residues. The estimates span major crops and agricultural regions of the United States. While the paper allows yields and nutrient-replacement costs to vary across counties, it uses the same cost parameters for all counties and crops. Chen and Önal (2012) develop a dynamic mathematical programming model and estimate the impact of U.S. biofuels mandates. To consider cropland allocation, they use historical crop mixes augmented by crop mixes estimated using acreage elasticities with respect to crop prices and lagged crop acreage. They find using historical and expanded crop mixes together reduces the inflexibility of supply response from using historical crop mixes alone.

Khanna et al. (2008) develop a dynamic land use allocation model that determines the profit maximizing land use choices to meet a targeted level of corn grain and cellulosic ethanol output in Illinois over the 16-year planning horizon of 2007-2022. The study includes corn stover, miscanthus and switchgrass as alternative cellulosic feedstocks. The model includes historical and hypothetical crop mixes to analyze future increases in crop land for feedstock production. The paper shows total greenhouse gas emissions over the period are reduced by $54 \%$ from the replacement of gasoline and total nitrogen use is increased by $25 \%$ from intensive corn production to produce stover.

Using a spatial equilibrium, non-linear programming model, Taylor and Koo (2010) determine the optimal number, locations and sizes of cellulosic ethanol processing plants in North Dakota. They use three feedstocks, wheat straw, corn stover and conservation reserve program (CRP) grasses, and consider $50 \%, 65 \%$ and $80 \%$ of available biomass is used for ethanol production. The model minimizes the sum of processing costs of biomass for ethanol, transportation costs of biomass from producing regions to ethanol plants and transportation costs of ethanol from processing plants to blending facilities. Results show that average plant size ranges from 75 to 110 million gallons per year and average total cost varies from $\$ 1.28$ to $\$ 1.95$ dollar per gallon of ethanol with three cases of biomass availability.

As in the study reported here, several papers use integrated economic and biophysical models to analyze the environmental impacts of crop production. In these studies, biophysical models such as the Soil and Water Assessment Tool (SWAT) (Arnold et al., 1998) and the Environmental Policy Integrated Climate (EPIC) model (Williams, 1995) are used to estimate the environmental impacts associated with changes in land use.

Nelson et al. (2006) analyze production of switchgrass on land used for grain production. Using SWAT model, they evaluate the impact of switchgrass production on water quality indicators, sediment yield, surface runoff and edge-of field erosion in the Delaware Basin in Northeast Kansas. The study finds the break-even receipts of $\$ 184$ to $\$ 363$ per hectare for switchgrass production, depending on the rate of nitrogen application, when replacing four conventional crop rotations. Using switchgrass yields from SWAT, they estimate the changes in crop mix associated with switchgrass production and the payments to switchgrass necessary to decrease sediment loads by $10 \%, 25 \%$ and $40 \%$.

Adams et al. (2005) integrate SWAT and a linear programming model of crop production including wheat, sorghum and peanut. Effluent levels estimated with SWAT are used in a mathematical programming model to measure the trade-off between farm income and levels of three pollutants, sediment, phosphorus and nitrogen, in the Ft. Cobb watershed in Southwestern Oklahoma. They estimate that reductions of 10\% and 20\% in sediment and nutrient runoff would decrease farm income by $2.3 \%$ and $4.7 \%$, respectively.

Kurkalova et al. (2010) integrate economic and environmental models to examine how alternative crop and corn stover prices affect the crop mix and stover availability in Iowa. They use the EPIC model to estimate the impact of stover removal on nutrient runoff and soil erosion. They show land use changes and environmental impacts 
for stover prices ranging from $\$ 0$ to $\$ 100 /$ metric ton. Kurkalova et al. (2010) is similar to our study in that the impacts of stover harvest on environmental outcomes and crop mixes are included. They use a single stover removal rate $(50 \%)$ and do not include other cellulosic feedstocks.

Egbendewe-Mondzozo et al. (2010) examines the land use change and environmental consequences from cellulosic feedstock production. They use EPIC and a regional economic model to study cellulosic biomass production in nine counties in Southern Michigan. EPIC is used to generate crop yields and environmental outcomes of water quality, soil erosion and greenhouse gas emissions. The regional economic model maximizes profit for a representative producer with nine biomass and 74 cropping systems including alternative crop rotations, tillage practices, land fertilities and residue removal rate. The model defines 71 regions by subdividing 37 watersheds into good and poor crop land. They show how cellulosic biomass production and crop land use change by increasing biomass price to $\$ 200 /$ metric ton. Corn stover production starts at $\$ 21 /$ metric ton and switchgrass becomes profitable at $\$ 46 /$ metric ton. Their approach is similar to our analysis in that they consider alternative crop mixes in a regional economic model. The analysis includes a single $50 \%$ rate of stover harvest and does not consider crop price changes.

\section{The Economic Model, Data and Analysis}

The economic model used for the study is a multi-region, linear programming model of the agriculture sector in the Le Sueur Watershed. The multi-region economic model captures a spatial market equilibrium by maximizing consumer plus producer surplus subject to market clearing constraints. Crop production activities for the sector allow the model to estimate supply behavior for grain and cellulosic biofuel feedstocks endogenously. The following linear programming model of an economic sector with multiple regions, multiple products and multiple variable and fixed inputs will illustrate the mathematical structure of the economic model.

$$
\text { Maximize: } \sum_{\mathrm{g} \in \Omega_{\mathrm{G}}} \sum_{\mathrm{i} \in \Omega_{\mathrm{Y}}} \mathrm{P}_{\mathrm{gi}} \mathrm{Y}_{\mathrm{gi}}-\sum_{\mathrm{g} \in \Omega_{\mathrm{G}}} \sum_{\mathrm{k} \in \Omega_{\mathrm{Z}}} \mathrm{R}_{\mathrm{gk}} \mathrm{Z}_{\mathrm{gk}}-\sum_{\mathrm{g} \in \Omega_{\mathrm{G}}} \sum_{\mathrm{h} \in \Omega_{\mathrm{G}}} \sum_{\mathrm{h} \in \Omega_{\mathrm{Y}}} \mathrm{ty}_{\mathrm{ghi}} \mathrm{TY}_{\mathrm{ghi}}-\sum_{\mathrm{g} \in \Omega_{\mathrm{G}}} \sum_{\mathrm{h} \in \Omega_{\mathrm{G}}} \sum_{\mathrm{h} \in \mathrm{g}} \mathrm{tz}_{\mathrm{ghk}} \mathrm{TZ}_{\mathrm{ghk}}
$$

$$
\begin{aligned}
& \text { Subject to: } Y_{\mathrm{gi}}-\sum_{1 \in \Omega_{\mathrm{GH}}} \sum_{\mathrm{j} \in \Omega_{\mathrm{XH}}} \mathrm{a}_{\mathrm{glj}} \mathrm{X}_{\mathrm{glj}}-\sum_{\substack{\mathrm{h} \in \Omega_{\mathrm{G}} \\
\mathrm{h} \neq \mathrm{g}}} \mathrm{TY}_{\mathrm{hgi}}+\sum_{\substack{\mathrm{h} \in \Omega_{\mathrm{G}} \\
\mathrm{h} \neq \mathrm{g}}} \mathrm{TY} \mathrm{ghi}_{\mathrm{g}} \leq 0 \mathrm{g \in \Omega _{ \textrm {G } }}, \mathrm{i} \in \Omega_{\mathrm{Y}} \\
& \sum_{1 \in \Omega_{\mathrm{GH}}} \sum_{\mathrm{j} \in \Omega_{\mathrm{X}}} \mathrm{e}_{\mathrm{gljk}} \mathrm{X}_{\mathrm{glj}}-\mathrm{Z}_{\mathrm{gk}}-\sum_{\substack{\mathrm{h} \in \Omega_{\mathrm{G}} \\
\mathrm{h} \neq \mathrm{g}}} \mathrm{TZ}_{\mathrm{hgk}}+\sum_{\substack{\mathrm{h} \in \Omega_{\mathrm{G}} \\
\mathrm{h} \neq \mathrm{g}}} \mathrm{TZ}_{\mathrm{ghk}} \leq 0 \mathrm{~g} \in \Omega_{\mathrm{G}}, \mathrm{k} \in \Omega_{\mathrm{Z}} \\
& \sum_{j \in \Omega_{X}} X_{g l j}=Q_{g l} g \in \Omega_{G}, l \in \Omega_{\mathrm{GH}} \\
& Y_{\text {gi }}, X_{g l j}, Z_{g k}, T Y_{\text {ghi }}, T Y_{\text {ghi }} \geq 0 \mathrm{~g} \in \Omega_{\mathrm{G}} ; \mathrm{i} \in \Omega_{\mathrm{Y}} ; \mathrm{l} \in \Omega_{\mathrm{GL}} ; \mathrm{j} \in \Omega_{\mathrm{X}} ; \mathrm{k} \in \Omega_{\mathrm{Z}} ; \mathrm{h} \in \Omega_{\mathrm{G}}, \mathrm{h} \neq \mathrm{g}
\end{aligned}
$$

Where $\Omega_{\mathrm{G}}$ is the set of regions, and $\Omega_{\mathrm{Y}}$ and $\Omega_{\mathrm{Z}}$ are the product and input sets, respectively. $\Omega_{\mathrm{GH}}$ is the set of HRU's mapped to regions, and $\Omega_{\mathrm{HX}}$ is the set of crop production activities mapped to HRU's. Variables include $\mathrm{Y}_{\mathrm{gi}}$, the quantity demanded of product $\mathrm{i}$ in region $\mathrm{g}, \mathrm{Z}_{\mathrm{gk}}$, the quantity supplied of variable input $\mathrm{k}$ in region $\mathrm{g}$, and $\mathrm{X}_{\mathrm{glj}}$ is the level of crop production activity $\mathrm{j}$ on hydrologic unit 1 in region $\mathrm{g}$. $\mathrm{Q}_{\mathrm{gl}}$ is the supply of cropland in hydrologic response unit 1 and region $\mathrm{g}$. $\mathrm{TY}_{\mathrm{ghi}}$ is the quantity of product $\mathrm{i}$ shipped from region $\mathrm{g}$ to region $\mathrm{h}$, and $\mathrm{TZ}_{\mathrm{ghk}}$ is the quantity of input $\mathrm{k}$ shipped from region $\mathrm{g}$ to region $\mathrm{h}$. $\mathrm{e}_{\mathrm{gij}}$ is the output of product $\mathrm{i}$ per unit of production activity $\mathrm{j}$ in region $\mathrm{g}$, and $\mathrm{e}_{\mathrm{gkj}}$ is the requirement of variable input $\mathrm{k}$ per unit of production activity $\mathrm{j}$. For each product and region, constraint [1] balances net production in the region plus shipments from other regions with regional demand plus shipments to other regions. Constraint [2] balances net use of variable input $\mathrm{k}$ in region g plus out-shipments with variable input supply plus in-shipments. Constraint [3] limits the sum of crop 
production activities in HRU 1 and region $g$ to no more than the area of that HRU, $\mathrm{Q}_{\mathrm{gl}}$. $\mathrm{ty}_{\mathrm{ghi}}$ and $\mathrm{tz}_{\mathrm{ghk}}$ are the unit transportation costs from region $\mathrm{g}$ to region $\mathrm{h}$ for product $\mathrm{i}$ and input $\mathrm{k}$, respectively, and $\mathrm{F}$ is fixed cost. In sector models covering a broad geographic region, such as national economic sectors, product demand and input supply are very often price responsive and prices are endogenous. As a small producing region, grain and input prices here, $\mathrm{P}_{\mathrm{gi}}$ and $\mathrm{R}_{\mathrm{gk}}$, respectively, are exogenous. However, since crop prices are critical to feedstock supply economics and a critical topic in much of the biofuels literature, the impacts of grain prices were considered here using alternative market price scenarios.

A multi-region framework is necessary to estimate feedstock transportation costs and their impacts on feedstock supply at the processing plant. Portions of five southern Minnesota counties and 47 townships fall within the Le Sueur Watershed. Township borders form a grid of six-mile by six-mile areas that are used as production and processing locations or regions in the model. Grain and cellulosic feedstock crop production activities were constructed for each region. The biofuels processing plant was assumed to be in a region central to the watershed. To derive the cellulosic feedstock supply response for the watershed, demand at the processing plant was fixed and the model was solved with the fixed demand parametrically increased from zero to near the capacity of the watershed. The optimal value of the dual variable for the feedstock constraint, then, provided the corresponding supply price for each quantity - a point on the estimated feedstock supply curve for the watershed.

In an endogenous supply, mathematical programming sector model, a key challenge is to characterize production so as to adequately capture the economic behavior reflected in the supply response of the firms in the sector. Disaggregating crop production according to homogeneous land types is critical both to expressing the economic outcomes and reflecting the impacts of feedstock production on water quality. To this end, the hydrologic response units defined in a study by Folle (2010) were used as land types in the economic model with unique technical coefficients for the crop production activities. A set of crop production activities was defined for each HRU or land type in a particular region. For the economic model of the Le Sueur, crop production activities were derived from a joint-product crop system based on a two-year rotation of corn and soybeans - the dominant cropping system in the region. Alternative production activities were constructed as variations of the prevailing cropping system (Note 1). As corn stover is one of the alternative feedstocks in the study, likely producer responses to the emergence of an expanding biofuels market would include both removing more of the available residue, corn stover, from corn acreage and expanding corn acreage within the region. Following the biophysical simulation results from Folle (2010), production activities for a three-year, corn-corn-soybean rotation were included. For each rotation, four rates of stover removal were included - no stover removal, $10 \%, 30 \%$ and $60 \%$. Assumed fertilization rates for corn were representative of actual practices in the watershed (Folle, 2010). 182.7 $\mathrm{kg} / \mathrm{ha}$ of ammonium phosphate was applied to first and second year corn. Anhydrous ammonia was applied at $134.5 \mathrm{~kg} / \mathrm{ha}$ for first year cost and $177.5 \mathrm{~kg} / \mathrm{ha}$ for second year corn, when stover was not harvested. When stover was collected, anhydrous ammonia rates were increased by 6,18 and $36 \mathrm{~kg} / \mathrm{ha}$ when stover harvest rates were $10 \%, 30 \%$ and $60 \%$, respectively. In line with assumptions made for the SWAT analysis, switchgrass was included as an alternative feedstock crop on three categories of crop land: HRU's with low productivity as measured by corn yields, steep land with slopes greater than two percent, and environmentally sensitive lands with relatively high effluent levels. The final alternative for producers was to idle crop land by participating in the Conservation Reserve Program (CRP). In all, there are up to ten crop production activities on each HRU land type - two corn-soybean rotations without stover harvest and with three alternative rates of stover removal, switchgrass as an energy crop, and CRP land. When the 4178 HRU's defined for the SWAT simulations are mapped to the regions in the economic model, there are a total of 9251 combinations of land types and regions, and a total of 92510 crop production activities.

Technical coefficients for the production activities are based on enterprise records for farms in the area, akgronomic recommendations, research trials and the biophysical simulation results. Most input requirements and production costs are based on farm records for south central Minnesota as reported by Lazarus (2011). Fertilizer and chemical use is based on assumptions for the SWAT analysis, which are representative of production practices in the Le Sueur (Folle, 2010). Each cropping system was simulated over a 13 year period from 1994 to 2006 generating estimated crop yields and effluent levels for each cropping system in each HRU (Folle, 2010). The Le Sueur basin (285 thousand ha) has a continental climate with cold dry winters and warm wet summers. Based on long term weather averages recorded at the Southern Research and Outreach Center of Waseca, the average monthly temperature ranged from $11^{\circ} \mathrm{F}$ in January to $71^{\circ} \mathrm{F}$ in July. The average annual precipitation ranged from $737 \mathrm{~mm}$ to $838 \mathrm{~mm}$. The Le Sueur basin has flat topography (0-2\% slope) with poorly drained mollisols formed in lacustrine deposits over $80 \%$ of its area, while the remainder is rolling topography with loamy soils formed in glacial moraines on slopes between $2-6 \%$. The SWAT model was calibrated using 
measured water quality and discharge data for the year 2000 from the 2096 ha Beauford watershed within the Le Sueur watershed. The model was then validated using measured water quality and discharge data from the years 2001-2004 from the Maple (88 thousand ha), Big Cobb (80 thousand ha) and Upper Le Sueur (117 thousand ha) watersheds within the Le Sueur Basin. Calibrated coefficients used in SWAT for the Le Sueur watershed are provided in Table 1, which also lists related default parameter values. Model performance during calibration and validation was very good, with Nash Sutcliffe efficiency values of 0.77 during calibration and 0.73 during validation.

Average annual grain and cellulosic feedstock yields and sediment, nitrate-nitrogen and phosphorus loads were used as technical coefficients for the crop production activities in the economic model. Technical coefficients for stover harvest were derived using conventional budgeting procedures and machine costs reported by Lazarus (2011). Parameters for the three-year corn soybean rotation are based on those for the two-year rotation. The economic model used in this study was constructed using the GAMS (Generalized Algebraic Modeling System) mathematical programming software (Rosenthal, 2010). The mathematical model presented earlier provides a conceptual framework for the sector model used in this study and the GAMS model as it was used here, with some practical differences. In the GAMS model, inputs and products may be classified as regional or non-regional as a means of managing essential spatial aspects of the markets. Effluents considered in the analysis, sediment, N-nitrate and phosphorus, were treated as products in the model, with zero prices, allowing their aggregated, watershed levels to be determined for each market equilibrium. Sediment, N-nitrate and phosphorus, along with corn stover and switchgrass, were classified as regional products and crop land by type was classified as a regional input. Other products, including corn grain and soybeans, and other inputs were classified as non-regional, implying uniform prices across the watershed. For each market and technical scenario considered, the model was solved with various levels of cellulosic feedstock demand at a hypothetical biofuels processing plant in a central region of the watershed. The optimal values of the dual variable for the demand constraint, then, provided an estimate of the equilibrium supply price at the plant.

Three grain market scenarios were defined to demonstrate cross price effects in the cellulosic feedstock supply response. For the base price scenario, the corn price was set at the average price paid to farmers in Minnesota from October 2010 through March 2011 of $\$ 4.62$ per bushel using USDA-NASS data. Ten years of monthly grain price data were used to calculate an average corn-soybean price ratio of 0.378 , which was used to calculate a baseline soybean price of $\$ 12.22$. Low and high soybean price scenarios were defined using corn-soybean price ratios one standard deviation below and above the ten year average price ratio. The resulting soybean prices were $\$ 10.83$ and $\$ 14.02$. In addition to grain price scenarios, limits on the rate of stover harvest were analyzed to evaluate the environmental impacts of this production decision. The four scenarios for corn stover removal were based on the alternative removal rates considered in the SWAT analysis. The base rate was assumed to be $60 \%$ of the collectable stover. Then stover removal was limited to $30 \%, 10 \%$ and $0 \%$ in order to limit water quality degradation. For the stover harvest rate scenarios, baseline grain prices were assumed.

Table 1. SWAT calibration of parameters governing surface and subsurface hydrology

\begin{tabular}{lccc}
\hline Parameter & Range & Default Value & Final Calibrated Value \\
\hline Curve Number & \pm 10 & - & -6 \\
Soil Available Water Capacity & $0.00-1.00$ & - & variable \\
Base-Flow Alpha Factor, Days & $0.10-1.00$ & 0.025 & 0.2 \\
Groundwater Revap. Coefficient & $0.02-0.20$ & 0.02 & 0.02 \\
Groundwater Delay Time, Days & $0.00-100$ & 40 & 20 \\
Time to Drain Soil to Field Capacity, Hours & & 24 & 48 \\
Drain Tile Lag Time, Hours & - & 96 & 96 \\
Depth to Subsurface Drain, mm & - & 1200 & 1200 \\
\hline
\end{tabular}

\section{Results}

For each grain market and stover harvest rate scenario, equilibrium solutions were found for nine annual demand levels at the processing plant of 0 to 800 thousand metric tons - near the stover production capacity of the 
watershed. The results are reported in Figures 2 through 7, and Tables 2 through 7 and will be discussed here, starting with those for the grain market price scenarios. Figure 2 shows the feedstock supply response within the watershed for base grain prices and under low and high soybean price scenarios. These marginal costs or supply prices are reported also in Table 2. Details of the corresponding equilibrium production activity levels and crop mixes are in Table 3 and effluent levels are in Table 4. Crop mixes by grain price scenario are shown also in Figure 3 and per hectare nitrate-N, phosphorus and sediment loads are shown in Figure 4.

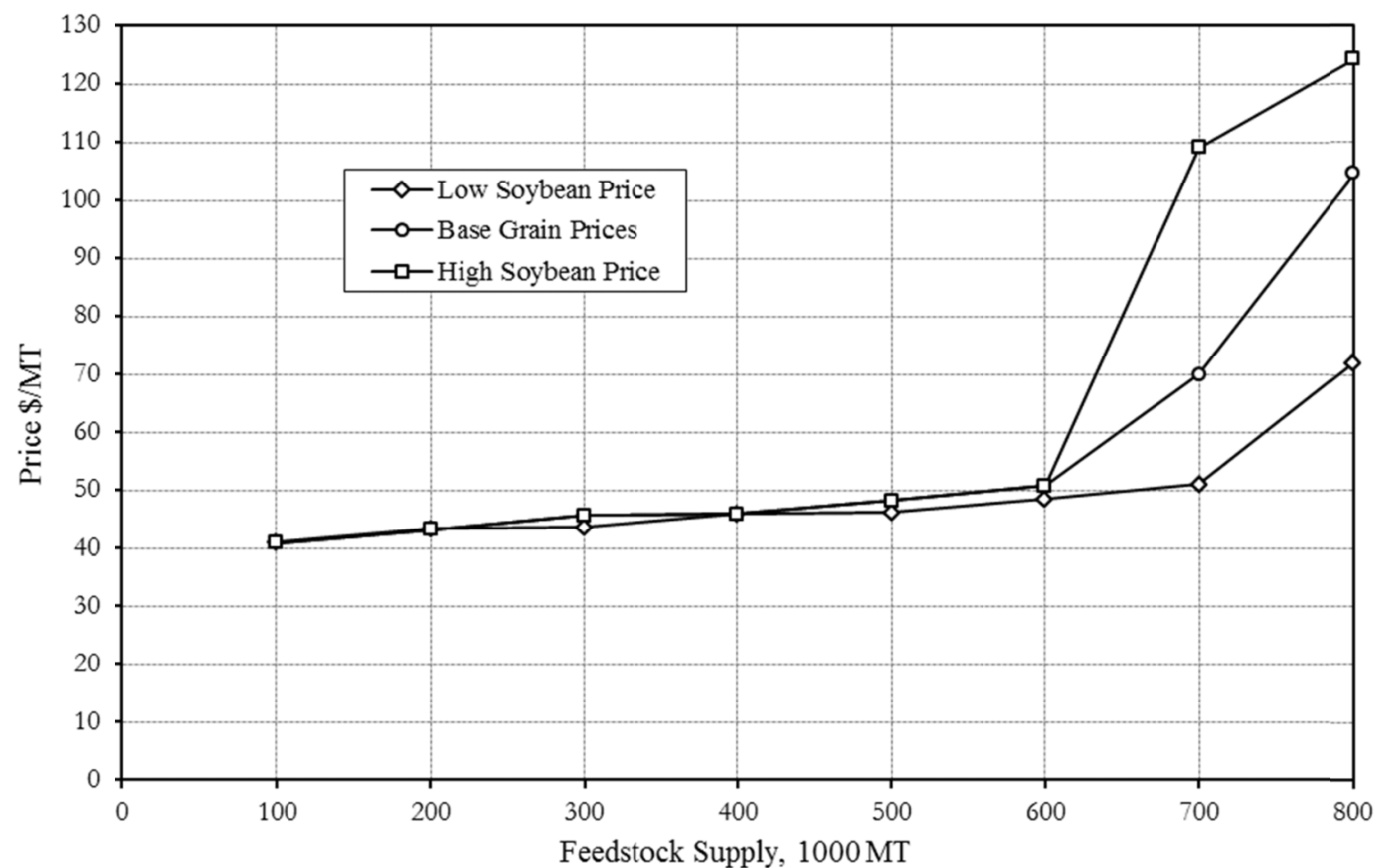

Figure 2. Feedstock supply in watershed by grain price scenario

Table 2. Marginal cost, $\$ / \mathrm{MT}$, at the plant by level of feedstock supply in the watershed for alternative grain price scenarios

\begin{tabular}{lrrrrrrrr}
\hline & \multicolumn{7}{c}{ Feedstock Production in the Watershed, 1000 MT } \\
Grain Price Scenario & \multicolumn{1}{c}{100} & \multicolumn{1}{c}{200} & \multicolumn{1}{c}{300} & \multicolumn{1}{c}{400} & \multicolumn{1}{c}{500} & \multicolumn{1}{c}{600} & \multicolumn{1}{c}{700} & \multicolumn{1}{c}{800} \\
\hline Low Soybean Price & $\$ 41.05$ & $\$ 43.38$ & $\$ 43.64$ & $\$ 45.93$ & $\$ 46.17$ & $\$ 48.48$ & $\$ 51.03$ & $\$ 72.08$ \\
Base Grain Prices & 40.95 & 43.24 & 45.60 & 45.94 & 48.22 & 50.76 & 70.02 & 104.45 \\
High Soybean Price & 40.95 & 43.24 & 45.60 & 45.94 & 48.21 & 50.76 & 109.04 & 124.25 \\
\hline
\end{tabular}

Under base grain prices, the marginal cost at the plant increases steadily from $\$ 40.95 /$ metric ton at a supply of 100 thousand tons to $\$ 50.76$ at 600 thousand tons as the feedstock, all corn stover, is transported longer distances to the plant. Crop mixes remain stable with stover collected from an increasing proportion of the watershed's corn production (see results for base grain prices in Table 3 and the center panel of Figure 3). As demand reaches 700 thousand tons, marginal cost jumps to $\$ 70.02$ as all stover from existing corn acreage is collected and expanded feedstock production requires an increase in the area of corn production in the watershed. The three-year corn-corn-soybean rotation becomes more prominent, and CRP area declines somewhat. A sharper supply price increase to $\$ 104.45$ occurs as feedstock production increases to 800 thousand metric tons, with corn area expanding further in the watershed and a very small area (61 hectares) of switchgrass produced. This expanded feedstock production is accompanied by further decreases in soybean production and CRP area within the watershed. 
Table 3. Crop rotations, crop mixes and CRP participation in hectares by grain price scenario

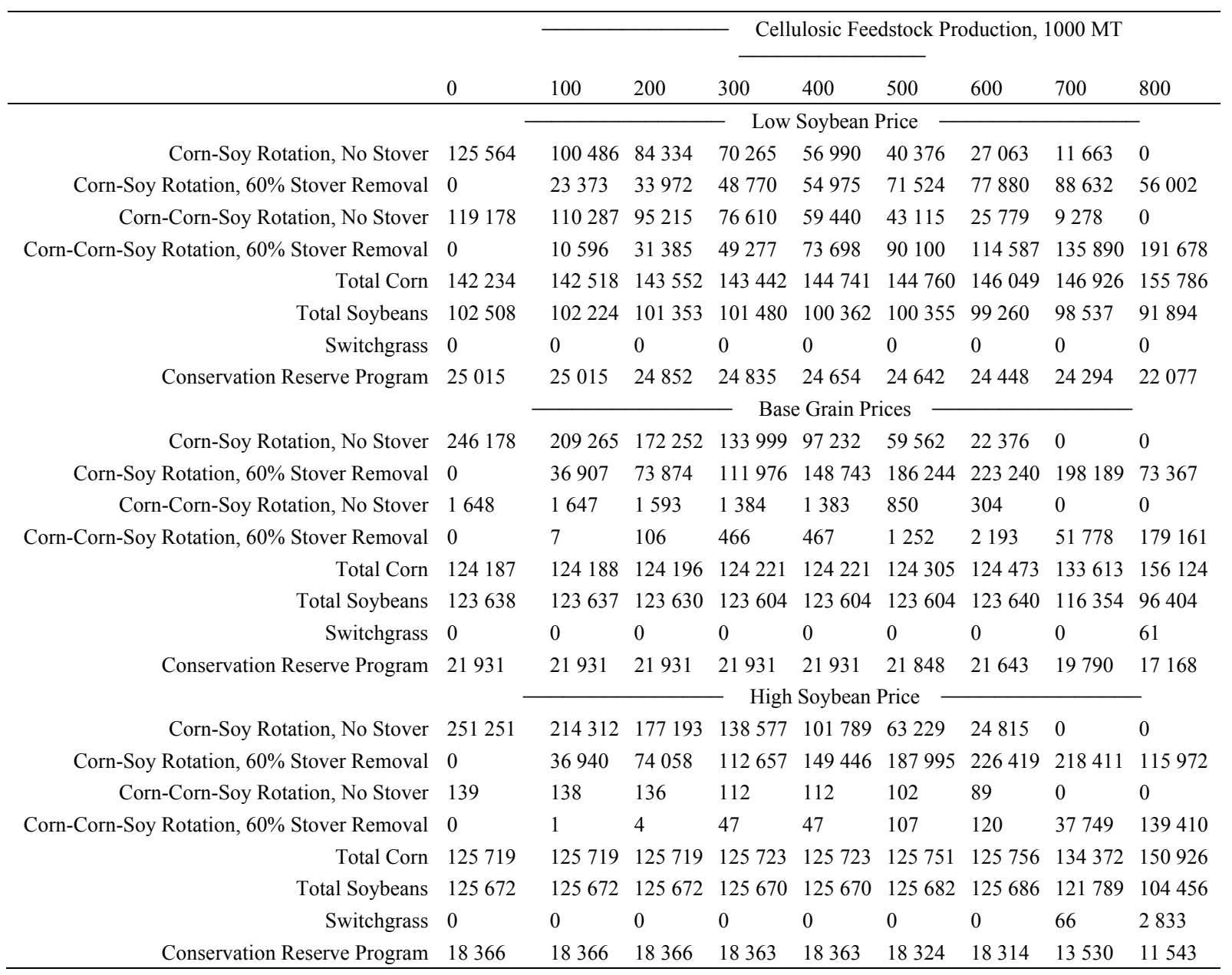

Changes in the price of soybeans have little impact on the marginal cost of feedstock supply until shifts occur in the crop mix at production levels above 600 thousand metric tons. With a low soybean price and no feedstock demand, more corn grain is produced and the potential exists to harvest more stover from the greater corn acreage within the watershed. A small increase in corn acreage occurs as feedstock production increases from 700 to 800 thousand metric tons and the supply price increases to $\$ 72.08$. With high soybean prices, corn acreage and marginal feedstock costs are again very similar to those under low soybean prices and base grain prices for feedstock demands from 0 to 600 . When feedstock production increases further to 700 thousand metric tons, marginal cost increases sharply to $\$ 109.04$ since increased corn area is required and the opportunity cost of expanding corn acreage is greater due to the high relative price of soybeans. A small area of switchgrass is produced. As demand increases to 800 thousand metric tons, marginal cost rises further to $\$ 124.25$, with corn area increasing to 151 thousand hectares and 28 hundred hectares of switchgrass produced.

The economic model accounts for total effluent levels in each region and the watershed as a whole. The average annual loads of nitrate-N, phosphorus and sediment are reported in Table 4 and shown in Figure 4. The effluent levels are reported in rates per hectare for the watershed - kilograms per hectare for nitrate- $\mathrm{N}$ and phosphorus, and metric tons per hectare for sediment. Nutrient loads are influenced by the mix of production activities in each HRU. Changes in water quality, then, result from changes in the crop mix and the rate and area of stover removal. For the results discussed so far, all corn stover is harvested at the highest rate included among the production activities, or $60 \%$. This is because the harvest cost per ton of stover increases slightly when the rate of stover removal declines (Note 2). The nitrate load per hectare increases very gradually as more feedstock is produced. The rate increases sharply, however, when increased stover production is accomplished in part by expanded corn production. The large increase in nitrate loads occurs sooner, at a demand level of 600 thousand tons, when the price of soybeans is relatively low and the opportunity cost of increasing stover supply near the plant by expanding corn acreage is lower. Notably, as supply reaches 800 thousand metric tons, nitrate loads spike to over $23 \mathrm{~kg} / \mathrm{ha}$ at both low soybean prices and base grain prices $-46 \%$ and $38 \%$ greater, respectively, 


\begin{tabular}{ll}
$\longrightarrow \longrightarrow$ Total Corn & $--\bullet$ Corn Grain and Stover \\
$\longrightarrow$ Switchgrass & $\longrightarrow$ Conservation Reserve Program \\
\hline
\end{tabular}
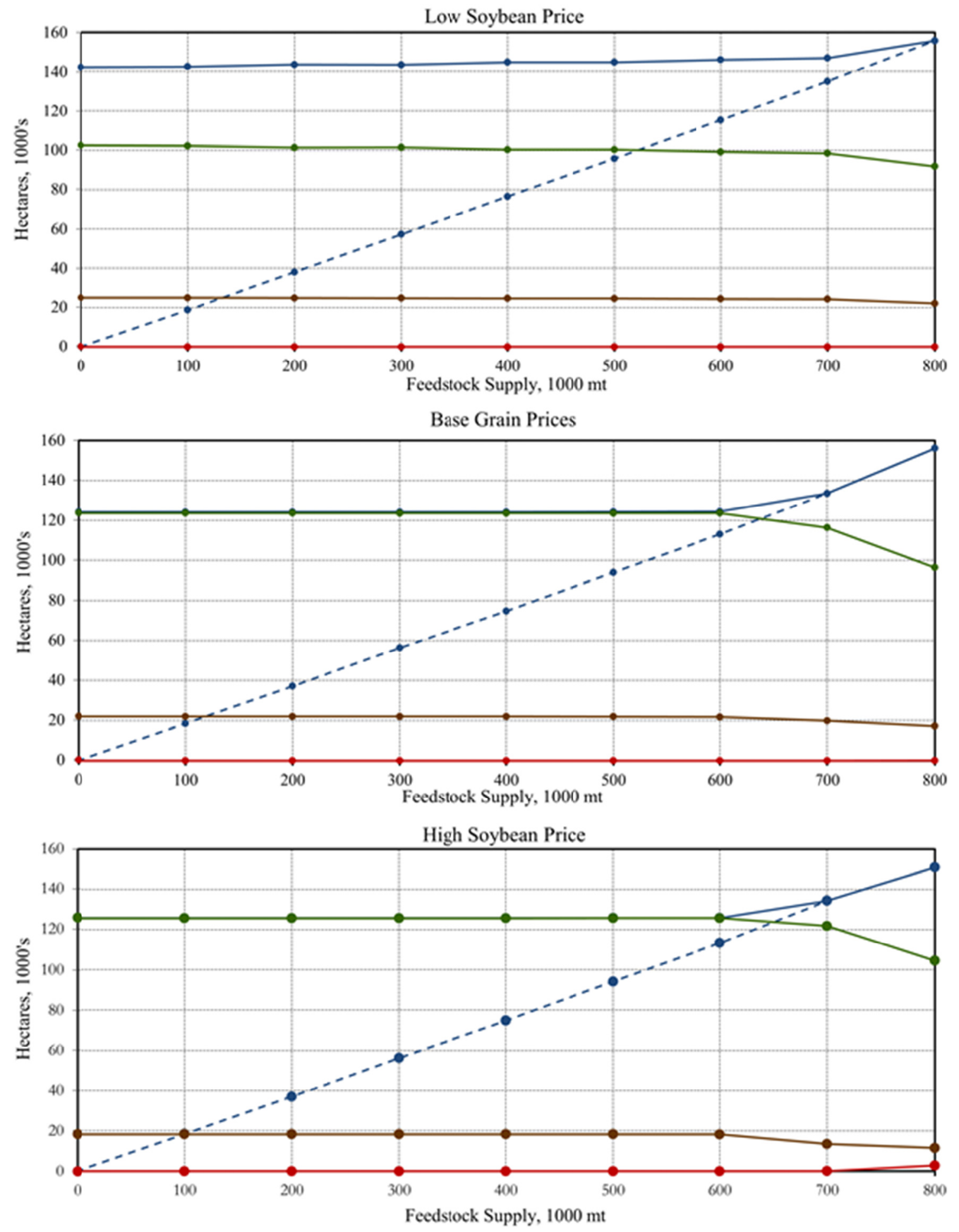

Figure 3. Crop mixes by watershed feedstock supply for alternative grain price scenarios 
Nitrate-N Load, Kg per Hectare

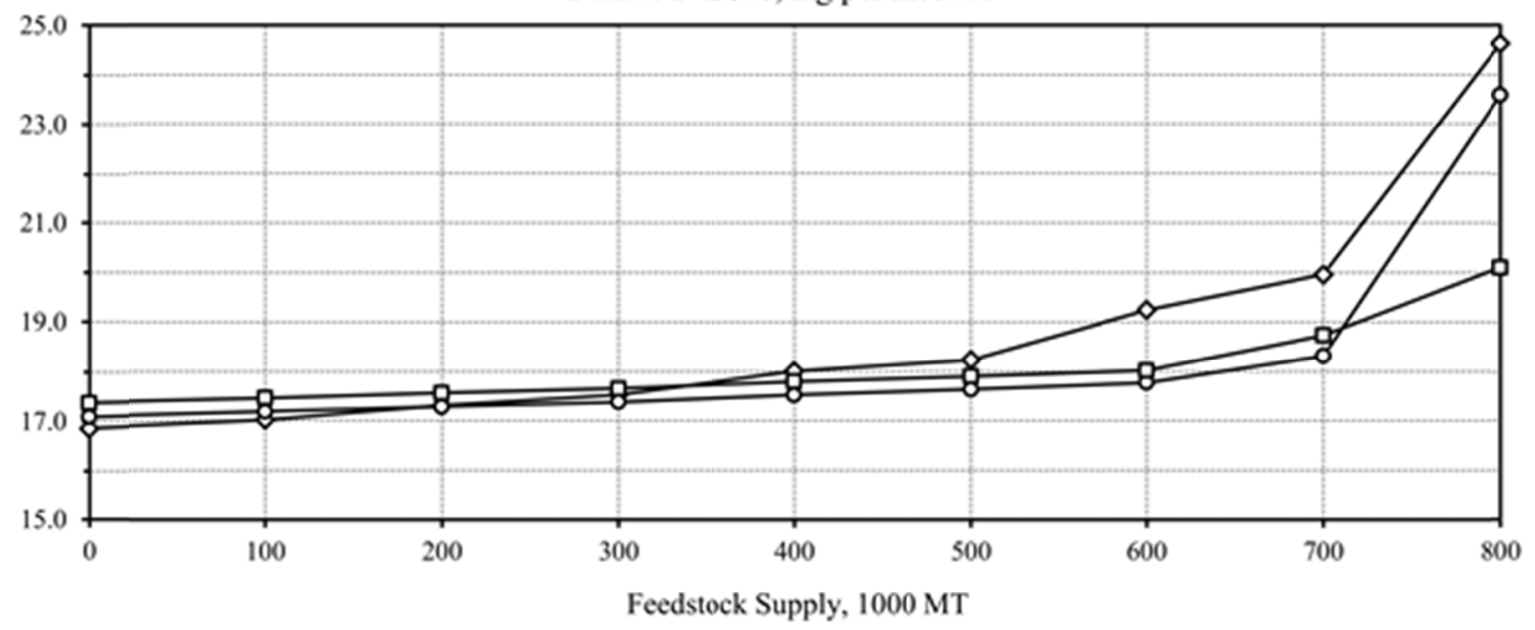

Phosphorus Load, Kg per Hectare

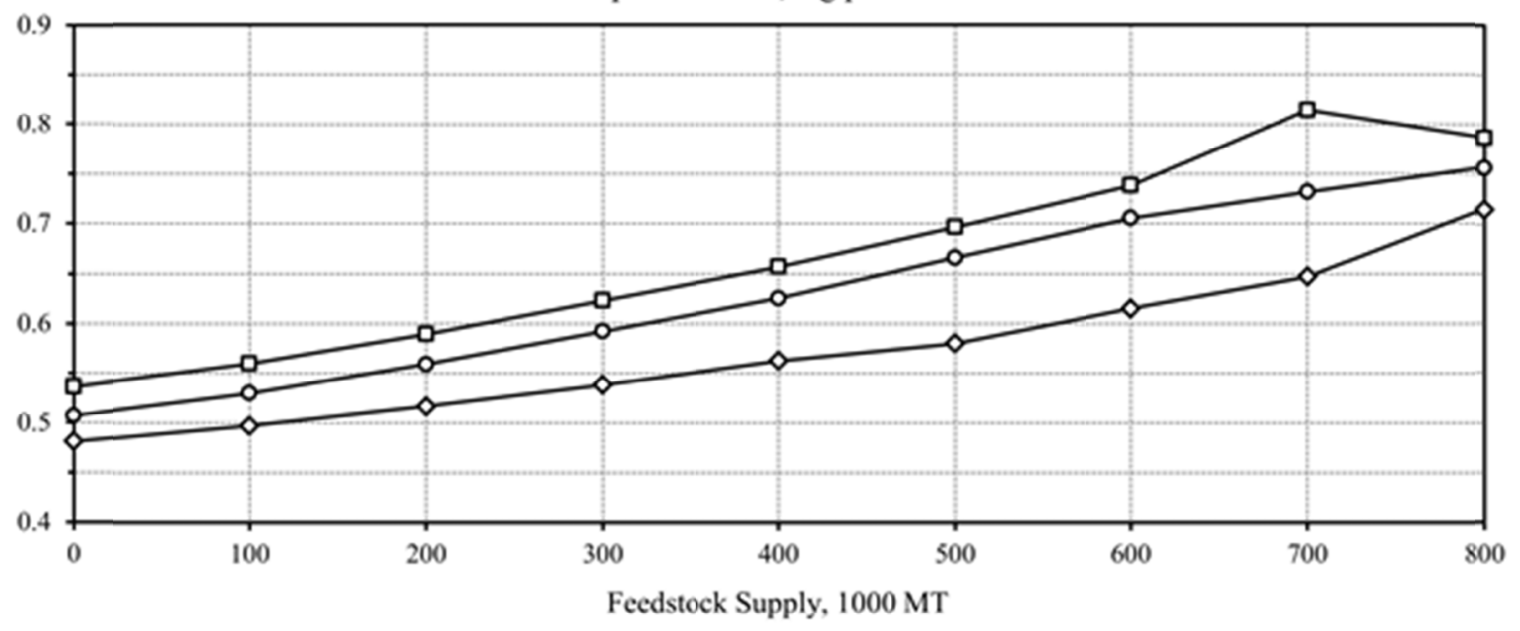

Sediment Load, MT per Hectare

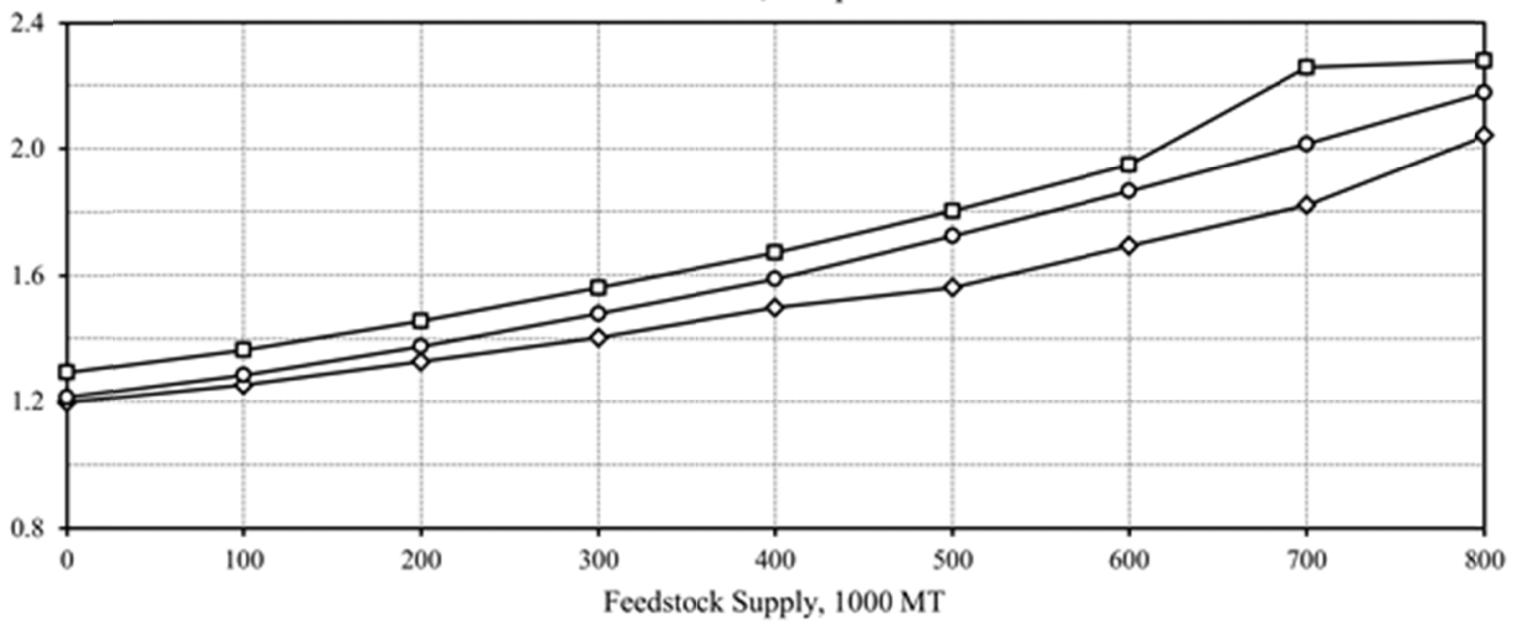

Figure 4. Effluent rates by watershed feedstock supply for alternative grain price scenarios 
Table 4. Effluent levels per hectare of crop land by grain price scenario

\begin{tabular}{|c|c|c|c|c|c|c|c|c|c|}
\hline \multirow[b]{2}{*}{ Scenario } & \multirow[b]{2}{*}{0} & \multirow[b]{2}{*}{100} & \multicolumn{5}{|c|}{ Cellulosic Feedstock Production, $1000 \mathrm{Mt}$} & \multirow[b]{2}{*}{700} & \multirow[b]{2}{*}{800} \\
\hline & & & 200 & 300 & 400 & 500 & 600 & & \\
\hline & & & & \multicolumn{3}{|c|}{ Nitrate-N Load, kg/ha } & & & - \\
\hline Low Soybean Price & 16.86 & 17.02 & 17.31 & 17.53 & 18.01 & 18.24 & 19.25 & 19.96 & 24.64 \\
\hline Base Grain Prices & 17.10 & 17.19 & 17.29 & 17.38 & 17.52 & 17.64 & 17.77 & 18.32 & 23.59 \\
\hline \multirow[t]{2}{*}{ High Soybean Price } & 17.37 & 17.46 & 17.56 & 17.65 & 17.80 & 17.90 & 18.02 & 18.74 & 20.11 \\
\hline & & & & \multicolumn{3}{|c|}{ Phosphorus Load, kg/ha } & & & \\
\hline Low Soybean Price & 0.48 & 0.50 & 0.52 & 0.54 & 0.56 & 0.58 & 0.62 & 0.65 & 0.72 \\
\hline Base Grain Prices & 0.51 & 0.53 & 0.56 & 0.59 & 0.63 & 0.67 & 0.71 & 0.73 & 0.76 \\
\hline \multirow[t]{2}{*}{ High Soybean Price } & 0.54 & 0.56 & 0.59 & 0.62 & 0.66 & 0.70 & 0.74 & 0.81 & 0.79 \\
\hline & & & & \multicolumn{3}{|c|}{ Sediment Load, Mt/ha } & & & \\
\hline Low Soybean Price & 1.20 & 1.25 & 1.33 & 1.40 & 1.50 & 1.56 & 1.69 & 1.82 & 2.04 \\
\hline Base Grain Prices & 1.21 & 1.28 & 1.38 & 1.48 & 1.59 & 1.72 & 1.86 & 2.01 & 2.18 \\
\hline High Soybean Price & 1.29 & 1.36 & 1.46 & 1.56 & 1.67 & 1.80 & 1.95 & 2.26 & 2.28 \\
\hline
\end{tabular}

than the loads when no feedstock is produced. The increase is less when the soybean price is high, because the higher feedstock demand is met in part by a small area of switchgrass production, which contributes less to nitrate loads than corn. In the high soybean price scenario, nitrate-N load per hectare increases from $17.4 \mathrm{~kg}$ when no feedstock market exists to 20.1 when 800 thousand metric tons is produced in the watershed - an increase of $16 \%$. Again, the largest jump in $\mathrm{N}$ load occurs when demand increases from 700 to 800 thousand tons and total corn acreage expands by $12 \%$.

Sediment yields and phosphorus loads are correlated and respond similarly to increased biofuel feedstock demand. With no feedstock production, average phosphorus load is 0.48 to $0.54 \mathrm{~kg} / \mathrm{ha}$, depending on the grain price scenario, and sediment yield is 1.20 to 1.29 metric tons/ha. Both effluents increase substantially as feedstock demand increases. The sediment yield is 1.82 to 2.26 metric tons/ha when feedstock supply reaches 700 and phosphorus load increases to 0.65 to $0.81 \mathrm{~kg} / \mathrm{ha}$. With both base and low soybean prices, phosphorus and sediment losses continue to increase significantly as production expands from 700 to 800 thousand tons. However, as was noted with nitrate load, when the soybean price is high and the increase in feedstock supply is met partially with switchgrass, sediment loss increases only slightly from 2.26 to 2.28 metric tons/ha, and phosphorus load declines form 0.81 to $0.79 \mathrm{~kg} / \mathrm{ha}$. Since corn stover removal has both environmental and agronomic costs not explicitly accounted for here, an analysis was conducted of the impacts of restrictions on the corn stover harvest rate on feedstock supply costs and water quality.

The base rate of stover removal assumed in this study is $60 \%$. Following the analysis by Folle (2010), alternative rates used in the construction of the crop production activities were $30 \%$ and $10 \%$, as well as no stover removal. The economic model of crop production in the watershed was used to derive the feedstock supply response with stover removal limited to $30 \%$ and $10 \%$ of the collectable cellulose, as well as a no corn stover removal scenario. Base grain prices were assumed. The results are reported in Tables 5-7 and Figures 5-7. For comparison, results for the base stover removal rate of $60 \%$ are repeated in the Tables and Figures.

Table 5 and Figure 5 show the dual values of the feedstock demand constraint as before, for eight demand levels from 100 to 800 thousand metric tons. Because the feedstock supply area for the plant would likely extend beyond the watershed that is the focus of this analysis, it is useful to interpret the results from the dual perspective. That is, the results show the supply response within the watershed to various prices at the plant. As expected, restricting the rate of corn stover harvest increases the marginal cost since the feedstock must be transported larger distances and higher cost production activities must be used. Recall that under base grain prices and with corn stover harvested at a $60 \%$ rate, stover is collected from all corn acreage and total corn area expands as supply within the watershed increases from 600 to 700 thousand tons. The implicit cost of the shift in the crop rotation is reflected in a sharp increase in the marginal cost of production. A still larger increase in marginal cost occurs when production increases to 800 thousand tons, as corn acreage is further expanded and some feedstock comes from switchgrass production. When the rate of stover harvest is restricted, these shifts in production activities occur at lower levels of feedstock supply in the watershed. 
Table 5. Marginal cost, \$/MT, at the plant by level of feedstock supply in the watershed with restrictions on corn stover harvest rate

\begin{tabular}{|c|c|c|c|c|c|c|c|c|}
\hline \multirow[b]{2}{*}{ Maximum Stover Harvest Rate } & \multirow[b]{2}{*}{100} & \multicolumn{6}{|c|}{ Feedstock Production in the Watershed, $1000 \mathrm{MT}$} & \multirow{2}{*}{$\overline{800}$} \\
\hline & & 200 & 300 & 400 & 500 & 600 & 700 & \\
\hline $60 \%$ Stover Harvest Rate & $\$ 40.95$ & $\$ 43.24$ & $\$ 45.60$ & $\$ 45.94$ & $\$ 48.22$ & $\$ 50.76$ & $\$ 70.02$ & $\$ 104.45$ \\
\hline $30 \%$ Stover Harvest Rate & 44.16 & 46.87 & 51.65 & 107.49 & 113.96 & 117.94 & 121.67 & 125.88 \\
\hline $10 \%$ Stover Harvest Rate & 55.28 & 106.95 & 110.49 & 113.75 & 117.05 & 120.14 & 124.76 & 132.67 \\
\hline Switchgrass Only, No Stover & 105.19 & 108.47 & 111.52 & 114.69 & 117.51 & 121.35 & 127.75 & 140.75 \\
\hline
\end{tabular}

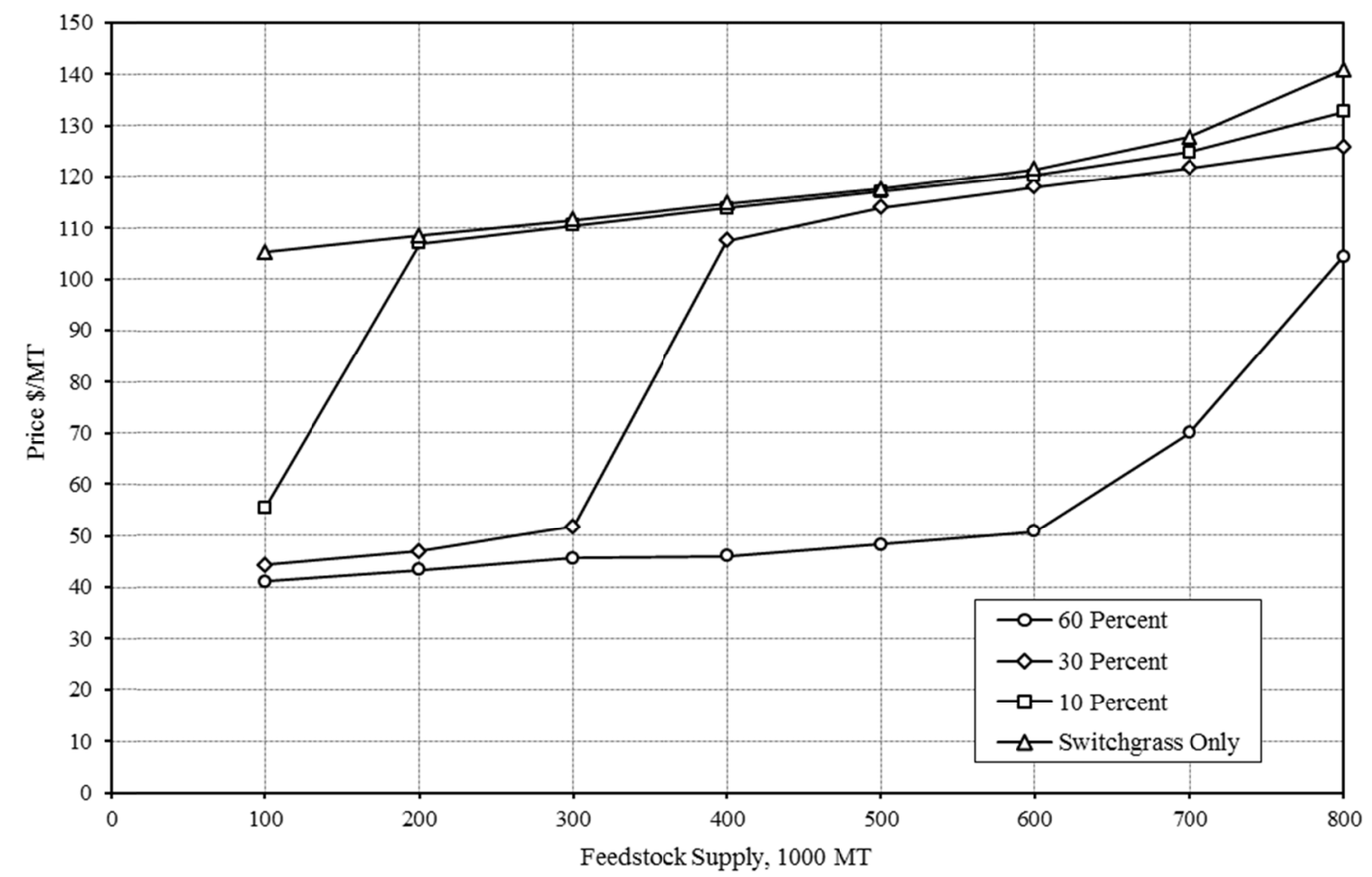

Figure 5. Feedstock supply in the watershed with restricted stover harvest rate

When the stover harvest rate is restricted to $30 \%$, the marginal cost of feedstock increases modestly for production levels up to 300 thousand tons, reflecting the greater distance over which the stover must be transported. To produce 400 thousand metric tons, corn acreage is expanded by 18 thousand hectares and three thousand hectares of switchgrass are produced. Marginal cost spikes from $\$ 51.65$ to $\$ 107.49$ per metric ton. As feedstock production increases from 400 to 500 thousand tons, total corn production, and stover production begin to decline, and corn, soybean, and CRP area within the watershed is displaced by switchgrass production. As feedstock production increases from 500 to 800 thousand tons, similar adjustments occur and marginal cost increases steadily to $\$ 125.88$. When the rate of stover harvest is limited to $10 \%$, the adjustment in production occurs earlier, with stover collected from all of the corn area when feedstock production is 200 thousand metric tons. At production levels from 300 to 800 thousand tons, corn grain and stover, and soybean production are displaced by switchgrass, which reaches almost 64 thousand hectares in area when total feedstock supply is 800 thousand metric tons. When corn stover harvest is not allowed and switchgrass is the only cellulosic feedstock, marginal cost ranges from $\$ 105.19$ at 100 to $\$ 140.75$ at 800 thousand metric tons. Switchgrass production steadily displaces corn and soybean production, and to a modest degree CRP land $-27.4 \%$ of cropland is in switchgrass when production reaches 800 thousand tons. Notably, limiting the rate of corn stover harvest also changes the relationship between the level of feedstock production in the watershed and water quality.

Effluent levels per hectare are reported in Table 7 and shown in Figure 7, across feedstock production levels, and for the three stover harvest rates plus the switchgrass only scenario. As noted earlier, with the base rate of $60 \%$ 
stover harvest and base grain prices, nitrate-N loads increase gradually from 17.10 kilograms per hectare when feedstock demand is zero to 18.32 kilograms per hectare at a demand of 700 thousand metric tons. A spike in $\mathrm{N}$ load to $23.59 \mathrm{~kg} / \mathrm{ha}$ occurs when demand reaches 800 thousand tons, reflecting the expansion of corn production and $\mathrm{N}$ fertilizer application in the watershed. When the stover harvest rate is restricted to $30 \%$, the impacts of feedstock production are similar up to 700 thousand tons, but slightly higher from 400 to 600 thousand tons as the lower harvest rate leads to more corn production and slightly higher nitrate-N loads. However, with a $30 \%$ stover harvest rate, the increase in feedstock production in the watershed from 700 to 800 thousand tons is accomplished with more switchgrass production rather than increased corn area, so the spike in N-nitrate load no longer occurs. A further decrease in the stover removal rate to $10 \%$ leads to even earlier reliance on switchgrass production for feedstock supply. As a consequence, the nitrate-N load increases only slightly from 17.10 to 17.11 $\mathrm{kg} / \mathrm{ha}$ as production goes from 0 to 100 thousand tons. Beyond 100 thousand metric tons of feedstock production, nitrogen loads in the watershed decline steadily as switchgrass production expands, for the most part displacing corn and soybean production. When feedstock production reaches 800 thousand tons, nitrate- $\mathrm{N}$ loads fall to $16.11 \mathrm{~kg} / \mathrm{ha}-6.4 \%$ lower than the level when no cellulosic feedstock market exists.

Table 6. Crop rotations, crop mixes and CRP participation in hectares with restrictions on the maximum stover harvest rate

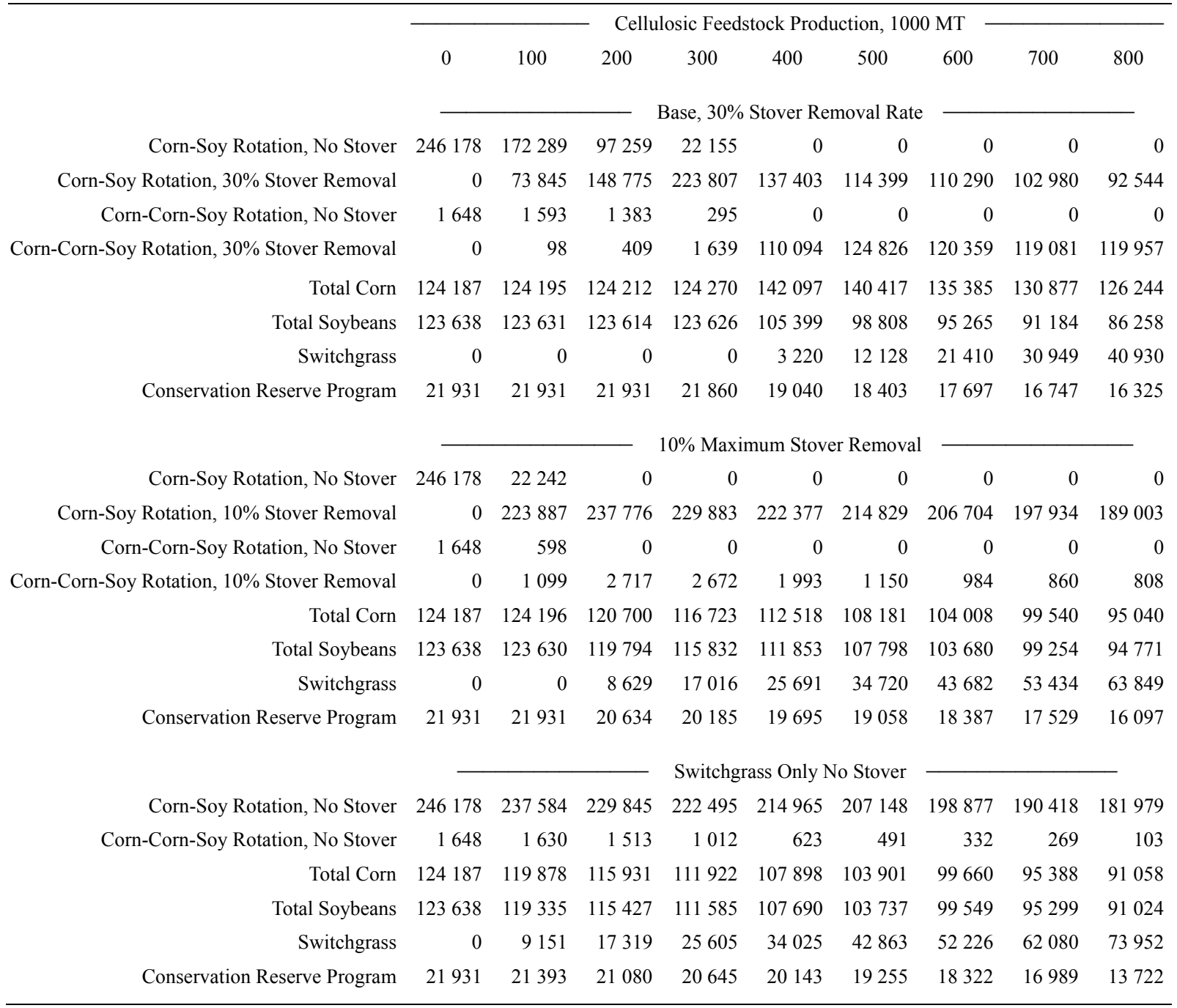




\begin{tabular}{|ll|}
$\longrightarrow \longrightarrow$ Total Corn & $-\cdots-$ Corn Grain and Stover \\
$\longrightarrow$ Switchgrass & $\longrightarrow$ Soybeans \\
\hline
\end{tabular}
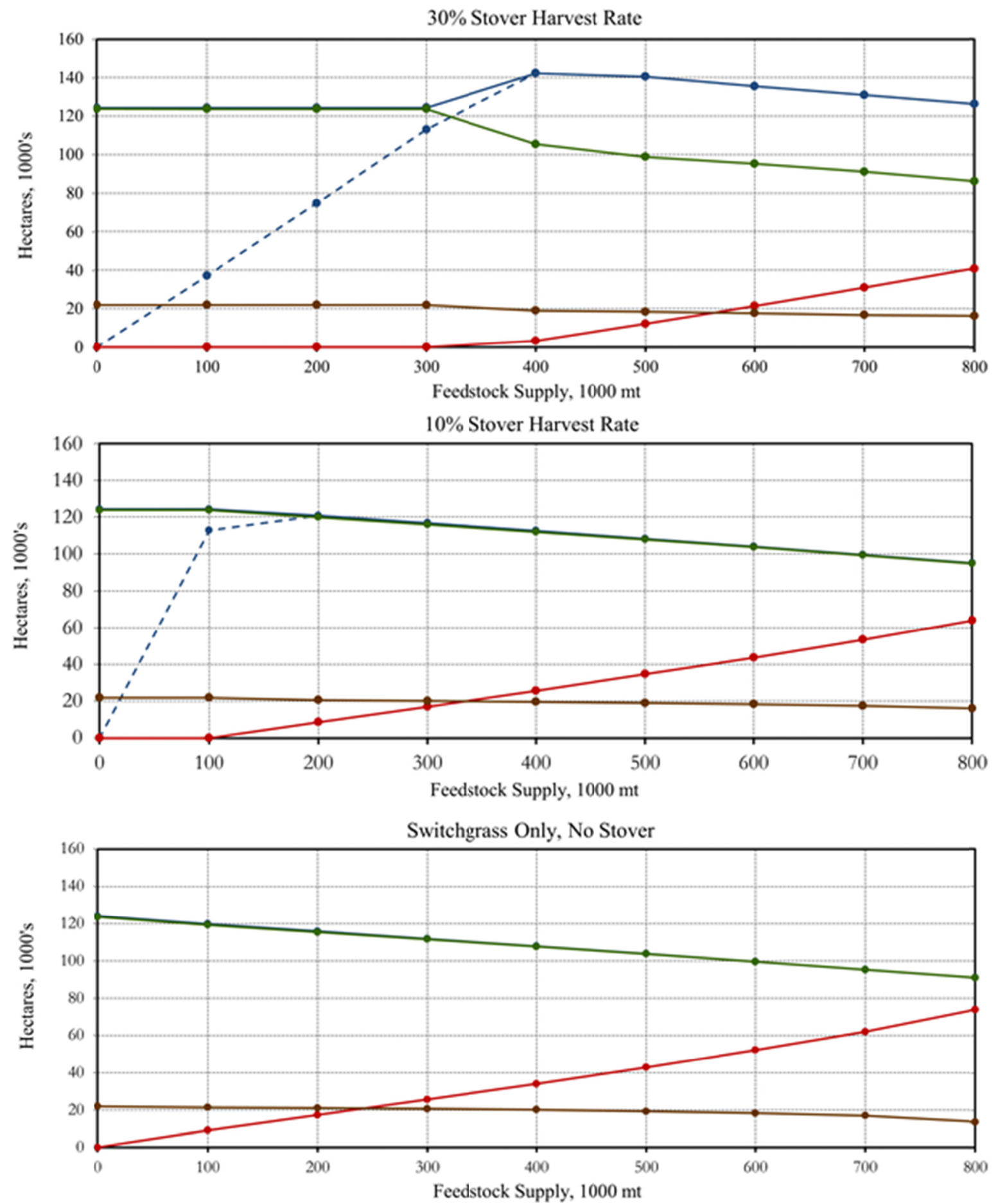

Figure 6. Crop mixes by watershed feedstock supply with restricted stover harvest rate 


\begin{tabular}{|ll|}
\hline$\rightarrow-$ Base, $60 \%$ Stover Removal Rate & $-\checkmark-30 \%$ Maximum Stover Removal \\
$\rightarrow-10 \%$ Maximum Stover Removal & $-\Delta-$ Switchgrass Only, No Stover \\
\hline
\end{tabular}
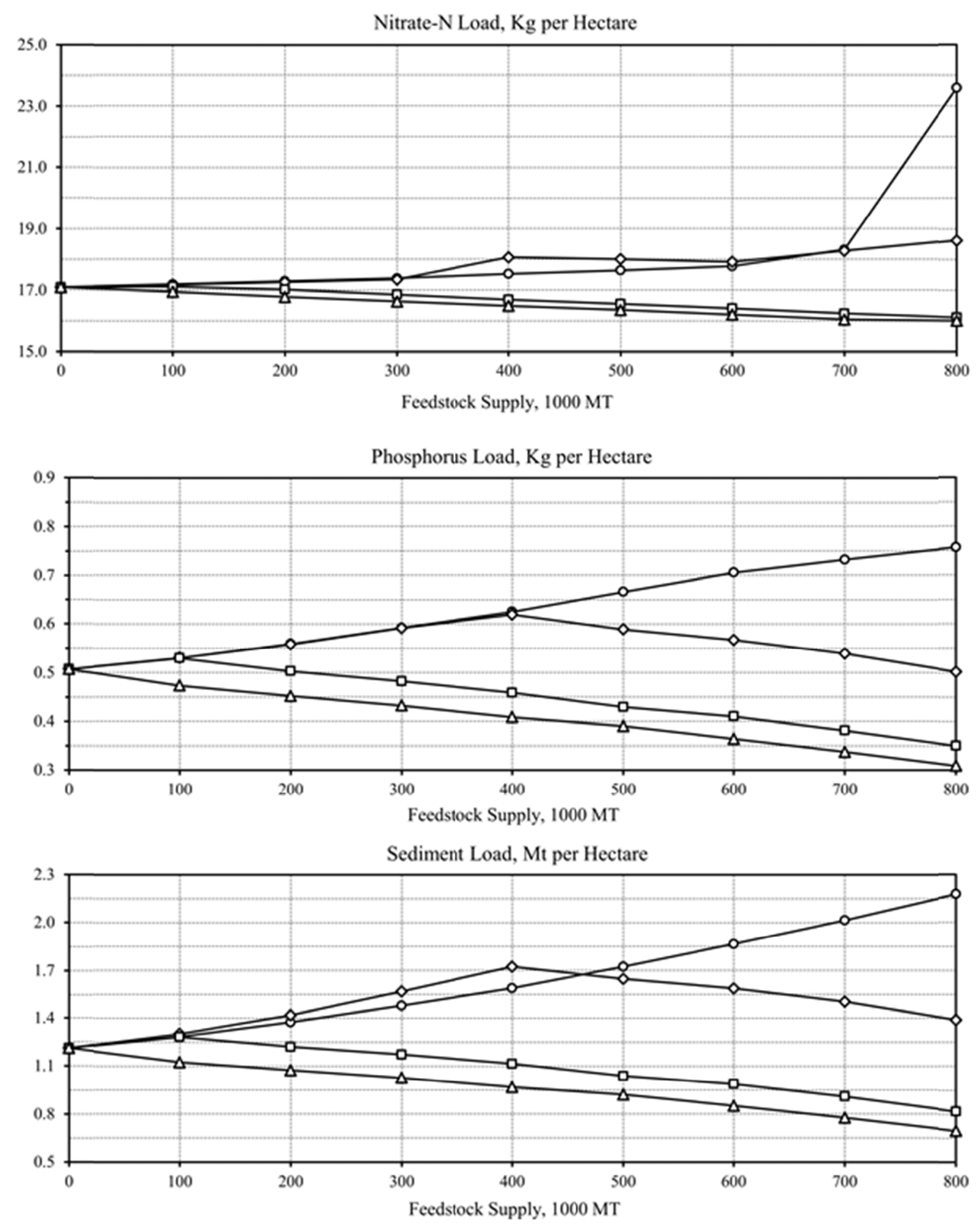

Figure 7. Effluent rates by watershed feedstock supply with restricted stover harvest rate 
Table 7. Effluent levels per hectare of crop land with restrictions on stover harvest rate

\begin{tabular}{|c|c|c|c|c|c|c|c|c|c|}
\hline \multirow[b]{2}{*}{ Scenario } & \multicolumn{2}{|c|}{[} & \multicolumn{5}{|c|}{ Cellulosic Feedstock Production, $1000 \mathrm{Mt}$} & \multirow[b]{2}{*}{700} & \multirow[b]{2}{*}{800} \\
\hline & 0 & 100 & 200 & 300 & 400 & 500 & 600 & & \\
\hline & & & & \multicolumn{3}{|c|}{ Nitrate-N Load, kg/ha } & & & \\
\hline Base, $60 \%$ Stover Removal Rate & 17.10 & 17.19 & 17.29 & 17.38 & 17.52 & 17.64 & 17.77 & 18.32 & 23.59 \\
\hline 30\% Maximum Stover Removal & 17.10 & 17.17 & 17.25 & 17.34 & 18.06 & 18.00 & 17.91 & 18.28 & 18.63 \\
\hline $10 \%$ Maximum Stover Removal & 17.10 & 17.11 & 17.02 & 16.86 & 16.69 & 16.55 & 16.41 & 16.24 & 16.11 \\
\hline Switchgrass Only, No Stover & 17.10 & 16.94 & 16.78 & 16.63 & 16.49 & 16.35 & 16.20 & 16.05 & 16.01 \\
\hline & & & & \multicolumn{3}{|c|}{ Phosphorus Load, kg/ha } & & & \\
\hline Base, $60 \%$ Stover Removal Rate & 0.507 & 0.530 & 0.559 & 0.592 & 0.625 & 0.666 & 0.705 & 0.732 & 0.757 \\
\hline $30 \%$ Maximum Stover Removal & 0.507 & 0.530 & 0.558 & 0.592 & 0.619 & 0.589 & 0.567 & 0.539 & 0.502 \\
\hline 10\% Maximum Stover Removal & 0.507 & 0.529 & 0.503 & 0.482 & 0.459 & 0.429 & 0.410 & 0.381 & 0.350 \\
\hline Switchgrass Only, No Stover & 0.507 & 0.473 & 0.452 & 0.432 & 0.409 & 0.390 & 0.364 & 0.337 & 0.309 \\
\hline Base $60 \%$ Stover Rem & 1213 & & 1375 & \multicolumn{3}{|c|}{ Sediment Load, Mt/ha } & 1865 & 2015 & 2.177 \\
\hline $30 \%$ Maximum Stover Removal & 1.213 & 1.302 & 1.419 & 1.568 & 1.723 & 1.646 & 1.587 & 1.503 & 1.389 \\
\hline $10 \%$ Maximum Stover Removal & 1.213 & 1.284 & 1.222 & 1.173 & 1.116 & 1.039 & 0.988 & 0.909 & 0.817 \\
\hline Switchgrass Only, No Stover & 1.213 & 1.125 & 1.074 & 1.027 & 0.968 & 0.921 & 0.851 & 0.776 & 0.695 \\
\hline
\end{tabular}

The impacts of restrictions on corn stover harvest rates on phosphorus loads and sediment yield are even more pronounced than the impacts on nitrate- $\mathrm{N}$ loads. As noted before, with a $60 \%$ stover harvest rate, phosphorus loads increase from $0.51 \mathrm{~kg} / \mathrm{ha}$ when no feedstock is produced to $0.76 \mathrm{~kg} / \mathrm{ha}$ when production reaches 800 thousand tons - an increase of 49 percent. With the harvest rate limited to $30 \%$, phosphorus loads increase as production expands to 400 thousand tons, but then decline as further feedstock production involves more land in switchgrass. When production in the watershed reaches 800 thousand tons, phosphorus loads have fallen to 0.50 $\mathrm{kg} / \mathrm{ha}$ - just below the level for no feedstock production. Limiting the stover removal rate to $10 \%$, phosphorus loads increase initially as production of feedstock goes from 0 to 100 thousand tons, then steadily declines with the expansion of switchgrass. Eventually, when production is 800 thousand tons, the phosphorus load has declined to $0.35 \mathrm{~kg} / \mathrm{ha}-31.0 \%$ less than when no feedstock is produced. With switchgrass as the only feedstock, phosphorus loads decline steadily as feedstock production expands, eventually declining to $0.31 \mathrm{~kg} / \mathrm{ha}$ when production is 800 thousand tons. Because phosphorus loads are related to soil loss, the sediment yield results largely mirror the phosphorus load results. With no restrictions on the stover harvest rate, sediment loss reaches 2.18 metric tons per hectare when feedstock production is 800 thousand metric tons, compared to 1.21 when no feedstock is produced. When switchgrass is the only feedstock, sediment yield declines by $42.7 \%$ to 0.70 metric tons/ha when production goes from 0 to 800 thousand metric tons. Each equilibrium solution yields marginal values or penalty costs associated with production activities that are non-basic in the optimal solution. These marginal values provide economic insights into how the sector may respond to exogenous shocks such as technological change or public policies and may provide valuable policy insights. In this study, penalty costs for switchgrass, the energy crop alternative in the analysis, is a good example. The sector model includes 6140 switchgrass production activities, each for a combination of HRU and region of the watershed. For many of the 63 optimal solutions (nine feedstock supply levels and six scenarios), all of the switchgrass activities have negative penalty costs and are non-basic. These margins represent the rate at which farm profit would decline if the switchgrass production activity increased. They reflect the direct costs of switchgrass production, the implicit values of the switchgrass feedstock yields, and the opportunity costs associated with the displacement of alternative crop production activities in the HRU's and regions. As an example, consider the base grain price scenario, the base rate of corn stover removal of $60 \%$, and a feedstock supply of 700 thousand metric tons. All 6140 switchgrass activities are non-basic and the average marginal value is $-\$ 335.50$ per hectare. With the same grain prices and feedstock supply, when the corn stover harvest rate is limited to $30 \%$, switchgrass production becomes economical and the average marginal value for the 4539 non-basic switchgrass production activities declines to $-\$ 137.37$ per hectare. More detailed results can be seen in Figure 8, which shows the frequency distributions of penalty costs for both scenarios. When the rate of corn stover removal is restricted, the implicit 
farm-gate values of feedstock increase and the opportunity costs of competing corn-based cropping systems decline. As a result, the distribution of switchgrass penalty costs shifts to the left. When studied under a variety of scenarios, results of this type can provide valuable insights regarding the responsiveness of energy crop producers to changes in feedstock production and conversion technologies, energy and grain markets, and water policies that favor energy crops.

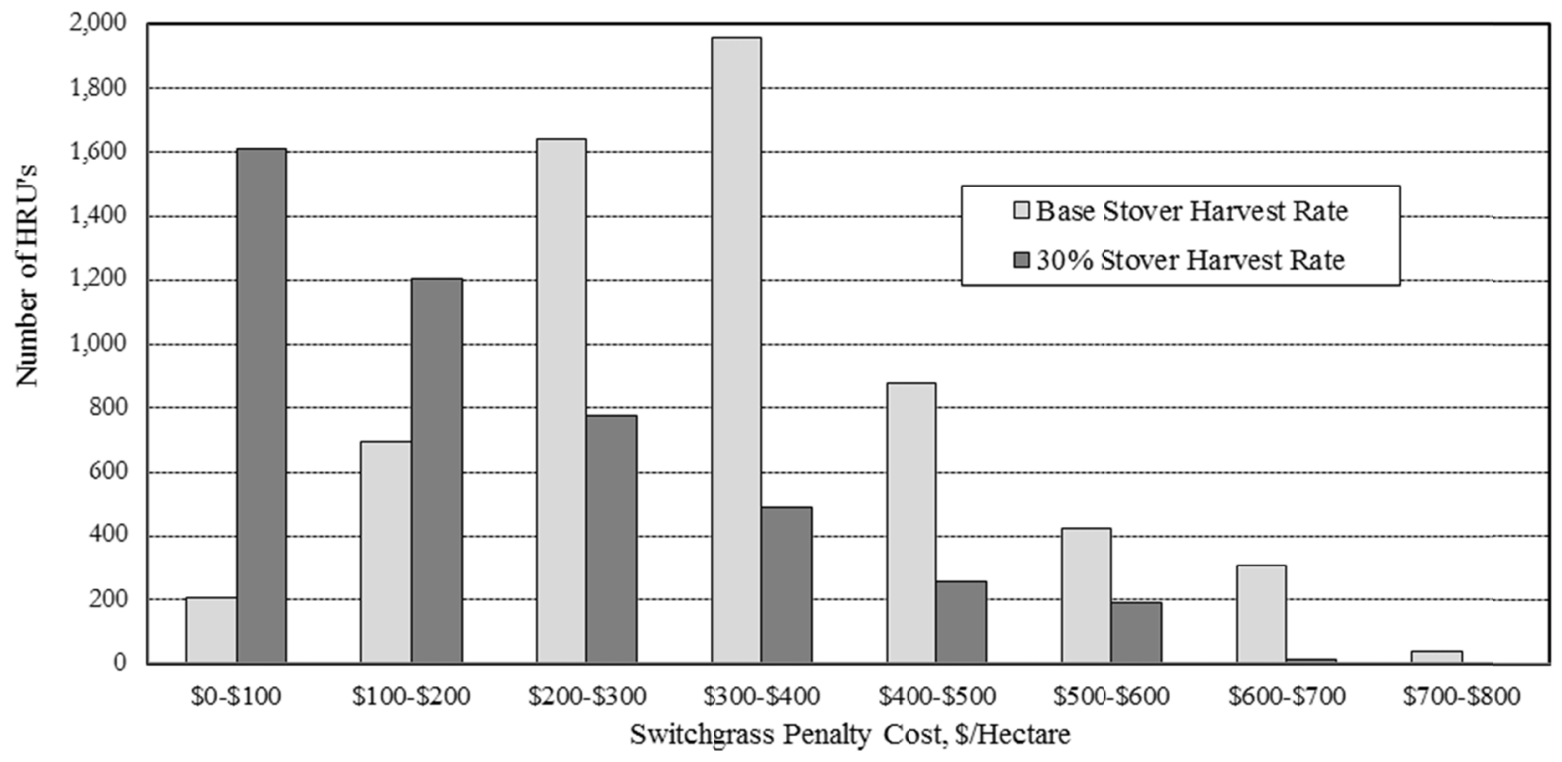

Figure 8 . Frequency distributions of switchgrass penalty costs with and without restrictions on corn stover harvest rates

Transportation costs figure prominently in the marginal cost of feedstock at the plant. Table 8 provides a summary of changes in shipping by level of feedstock production in the watershed for each of the scenarios analyzed, showing the average distance feedstock is transported. Shipping distances for all levels of feedstock production are shortest in the low soybean price scenario, when relatively more corn is produced and therefore more stover can be harvested close to the plant. As expected, the shipping distances generally increase as more feedstock is produced. However, that pattern can change if the value of feedstock becomes high enough to make higher cost crop mixes profitable close to the plant. For example, as supply increases from 700 to 800 thousand metric tons with base and high soybean prices, an increase in corn production and a modest amount of switchgrass production leads to a small decline in average distance shipped. With higher transportation costs, economic pressure to shift the crop mix in order to produce more feedstock close to the plant would increase.

Table 8. Shipping distances, kilometers per metric ton of feedstock

\begin{tabular}{lrrrrrrrr}
\hline & \multicolumn{8}{c}{ Cellulosic Feedstock Production, 1000 Mt } \\
\cline { 2 - 9 } Scenario & 100 & 200 & 300 & 400 & 500 & 600 & 700 & 800 \\
\hline Low Soybean Price & 7.05 & 11.45 & 14.07 & 16.95 & 19.34 & 21.74 & 24.33 & 26.53 \\
Base Grain Prices & 7.36 & 12.44 & 15.12 & 18.57 & 21.30 & 24.41 & 26.78 & 26.60 \\
High Soybean Price & 7.34 & 12.41 & 15.05 & 18.51 & 21.21 & 24.29 & 26.90 & 26.75 \\
30\% Maximum Stover Removal & 12.46 & 18.58 & 24.46 & 26.52 & 25.93 & 26.38 & 26.96 & 27.43 \\
10\% Maximum Stover Removal & 24.55 & 24.64 & 24.97 & 25.84 & 26.98 & 27.49 & 28.12 & 29.04 \\
Switchgrass Only, No Stover & 21.44 & 23.36 & 25.41 & 26.59 & 27.29 & 28.08 & 29.11 & 29.36 \\
\hline
\end{tabular}




\section{Conclusions}

A regional economic model of agricultural production in the Le Sueur Watershed in South Central Minnesota is constructed to analyze the economic and environmental impacts of cellulosic feedstock production. Production of two feedstocks, corn stover and switchgrass, is included in the model. Detailed production and environmental coefficients for the crop production activities in the sector model were based on a biophysical simulation analysis of the watershed with 4178 homogeneous areas of crop land - HRU's or hydrologic response units. Various market and production scenarios are considered in the analysis to identify the crop mix changes associated with feedstock production and to evaluate the impacts of the production on sediment, phosphorus and nitrogen losses.

As cellulosic feedstock production increases, production of corn stover expands farther from the biorefinery plant over an increasing proportion of the watershed and ultimately leads to an expansion of corn production in the watershed. A low relative soybean price reduces the opportunity cost associated with shifting land to corn production and reduces the marginal cost of supplying stover. As intensive corn production expands, water quality worsens, particularly from increased nitrogen loads. Switchgrass production appears when there are restrictions on the rate of stover harvest. The scenario allowing only a $10 \%$ stover harvest rate shows a significant decrease in nitrate-N losses owing to switchgrass production. However, if switchgrass is the only biofuel feedstock, the marginal cost of feedstock supply increases to over $\$ 100 /$ metric tons. While corn stover has a relatively low marginal cost compared to switchgrass, the sediment and nutrient losses associated with corn production make switchgrass more promising on environmental grounds. As a co-product of corn grain production, corn stover is an even more attractive cellulosic feedstock when grain prices are high. With current crop technologies and market conditions, and in the absence of policy incentives, the marginal cost of switchgrass will limit its use as a feedstock.

By integrating biophysical simulation analyses of cropping systems at the watershed level with economic models of the agriculture sector, it is possible to determine efficient tradeoffs between cellulosic feedstock production and various measures of water quality. Such tradeoffs will be critical to the analysis of bioenergy and environmental policies. The framework used in this study could be extended to include a broader range of production practices and cropping technologies that have the potential to reduce feedstock supply costs and improve environmental outcomes. Mitigation of the water quality impacts of feedstock production through investments in watershed infrastructure, such as buffer strips along streams or bank stabilization structures, could be evaluated, also, to determine the social costs of such investments endogenously along with the most efficient feedstock production alternatives.

The paper analyzes the impact of cellulosic feedstock production in a typical watershed in the corn-belt region. The knowledge gained and the methodologies used in this paper can be applied to other regions, feedstocks and biofuels. Cropland use and environmental impacts of feedstock production would be different if alternative feedstocks and crop production technologies are considered. The focus of the analysis reported here is on feedstock supply. The demand side of feedstock markets could be addressed by including biofuel processing in the sector model, making the derived demand for feedstock endogenous. By including detailed processing alternatives, important economic questions such as the substitution of alternative feedstocks and the optimal use of biofuel co-products could be studied. This framework would support the study of organizational aspects of the biofuels industry, also, including optimal conversion technologies, logistics, plant size and plant location, given market conditions, and energy and environmental policies. The analysis here presumes a competitive biofuels market. The model could be adapted to look at the impacts of imperfect competition in cellulosic feedstock markets, also. Linking of the economic model with a biophysical simulation model like SWAT, as was done in this study, could support an analysis of the risk associated with fluctuations in feedstock supply as a result of yield variability. Strategies to manage such risk, such as diversifying the types of feedstocks or developing flexible production contracts with feedstock producers could also be examined.

\section{References}

Adams, D. L., Boyer, T. A., \& Dicks, M. R. (2005). Changes in the Spatial Allocation of Cropland in the Ft. Cobb Watershed as a Result of Environmental Restrictions. Paper presented at Southern Agricultural Economics Assoc. Annual Meetings, February 5-9, Little Rock, Arkansas.

Arnold, J. G., \& Fohrer, N. (2005). SWAT 2000: Current Capabilities and Research Opportunities in Applied Watershed Modeling. Hydrological Processes, 19(3), 563-572. http://dx.doi.org/10.1002/hyp.5611

Arnold, J. G., Srinivasan, R., Muttiah, R. S., \& Williams, J. R. (2007). Large Area Hydrologic Modeling and Assessment Part I: Model Development 1. Journal of the American Water Resources Association, 34(1), 
73-89. http://dx.doi.org/10.1111/j.1752-1688.1998.tb05961.x

Brechbill, S. C., Tyner, W. E., \& Ileleji, K. E. (2011). The Economics of Biomass Collection and Transportation and its Supply to Indiana Cellulosic and Electric Utility Facilities. BioEnergy Research, 4(2), 141-152. http://dx.doi.org/10.1007/s12155-010-9108-0

Chen, X., \& Önal, H. (2012). Modeling Agricultural Supply Response Using Mathematical Programming and Crop Mixes. American Journal of Agricultural Economics, 94(3), 674-686. http://dx.doi.org/10.1093/ajae/aar143

Duffy, M. (2009). Estimated Costs of Crop Production-2010. Iowa Cooperative Extension Service Bulletin No. FM 1712.

Egbendewe-Mondzozo, A., Swinton, S. M., Izaurralde, C. R., Manowitz, D. H., \& Zhang, X. (2012). Maintaining Environ-mental Quality While Expanding Energy Biomass Production: Policy Simulations from Michigan, USA. Paper presented at 2012 Conference, August 18-24, Foz do Iguacu, Brazil.

Egbendewe-Mondzozo, A., Swinton, S. M., Izaurralde, C. R., Manowitz, D. H., \& Zhang, X. (2011). Biomass Supply from Alternative Cellulosic Crops \& Crop Residues: A Spatially Explicit Bioeconomic Modeling Approach. Biomass \& Bioenergy, 35(11), 4636-4647. http://dx.doi.org/10.1016/j.biombioe.2011.09.010

Farrell, A. E., Plevin, R. J., Turner, B. T., Jones, A. D., O'Hare, M., \& Kammen, D. M. (2006). Ethanol can Contribute to Energy and Environmental Goals. Science, 311(5760), 506-508. $\mathrm{http}: / / \mathrm{dx}$. doi.org/10.1126/science.1121416

Folle, S. M. (2010). SWAT Modeling of Sediment, Nutrients and Pesticides in the Le-Sueur River Watershed, South-Central Minnesota. (Unpublished Ph.D. thesis), University of Minnesota, Minneapolis, MN.

Gallagher, P. W., Dikeman, M., Fritz, J., Wailes, E., Gauthier, W., \& Shapouri, H. (2003). Supply and Social Cost Estimates for Biomass from Crop Residues in the United States. Environmental and Resource Economics, 24(4), 335-358. http://dx.doi.org/10.1023/A:1023630823210

Hertel, T. W., Golub, A. A., Jones, A. D., O'Hare, M., Plevin, R. J., \& Kammen, D. M. (2010). Effects of U.S. Maize Ethanol on Global Land Use and Greenhouse Gas Emissions: Estimating Market-Mediated Responses. Bioscience, 60(3), 223-231. http://dx.doi.org/10.1525/bio.2010.60.3.8

Hill, J., Polasky, S., Nelson, E., Tilman, D., Huo, H., Ludwig, L., Neumann, H., Zheng, H., \& Bonta, D. (2009). Climate Change and Health Costs of Air Emissions from Biofuels and Gasoline. Proceedings of the National Academy of Sciences, 106(6), 2077-2082. http://dx.doi.org/10.1073/pnas.0812835106

Hoekman, S. K. (2009). Biofuels in the U.S.-Challenges and Opportunities. Renewable Energy, 34(1), 14-22. http://dx.doi.org/10.1016/j.renene.2008.04.030

Huang, H. J., Ramaswamy, S., Al-Dajani, W., Tschirner, U., \& Cairncross, R. A. (2009). Effect of Biomass Species and Plant Size on Cellulosic Ethanol: A Comparative Process and Economic Analysis. Biomass and Bioenergy, 33(2), 234-246. http://dx.doi.org/10.1016/j.biombioe.2008.05.007

Khanna, M., Hochman, G., Rajagopal, D., Sexton, S., \& Zilberman, D. (2009). Sustainability of Food, Energy and Environment with Biofuels. CAB Reviews: Perspectives in Agric, Veterinary Science, Nutrition \& Natural Resources, 4(028), 1-10. http://dx.doi.org/10.1079/PAVSNNR20094028

Khanna, M., Önal, H., Chen, X., \& Huang, H. (2010). Meeting Biofuels Targets: Implications for Land Use, Greenhouse Gas Emissions, and Nitrogen Use in Illinois. Handbook of Bioenergy Economics and Policy, 33, 287-305. http://dx.doi.org/10.1007/978-1-4419-0369-3_17

Khanna, M., Chen, X., Huang, H., \& Önal, H. (2011). Supply of Cellulosic Biofuel Feedstocks and Regional Production Pattern. American Journal of Agricultural Economics, 93(2), 473-80. http://dx.doi.org/10.1093/ajae/aaq119

Kurkalova, L. A., Secchi, S., \& Gassman, P. W. (2010). Corn Stover Harvesting: Potential Supply and Water Quality Implications. Handbook of Bioenergy Economics and Policy, 33, 307-323. http://dx.doi.org/10.1007/978-1-4419-0369-3_18

Lazarus, W. F. (2010). Minnesota Crop Cost and Return Guide for 2011. University of Minnesota Extension, St. Paul, Minnesota.

Morey, R. V., Kaliyan, N., Tiffany, D. G., \& Schmidt, D. R. (2010). A Corn Stover Supply Logistics System. Applied Engineering in Agriculture, 26(3), 455-461. http://dx.doi.org/10.13031/2013.29946 
Neitsch, S. L., Arnold, J. G., Kiniry, J. R., Srinivasan, R., \& Williams, J. R. (2004). Soil and Water Assessment Tool Input/Output File Documentation Version 2005. Grassland. Soil and Water Research Laboratory, Agricultural Research Service, Blackland Research Center, Texas Agricultural Experiment Station.

Nelson, R. G., Ascough, J. C., \& Langemeier, M. R. (2006). Environmental and Economic Analysis of Switchgrass Production for Water Quality Improvement in Northeast Kansas. Journal of Environmental Management, 79(4), 36-347. http://dx.doi.org/10.1016/j.jenvman.2005.07.013

Petrolia, D. R. (2008). The Economics of Harvesting and Transporting Corn Stover for Conversion to Fuel Ethanol: A Case Study for Minnesota. Biomass and Bioenergy, 32(7), 603-612. http://dx.doi.org/10.1016/j.biombioe.2007.12.012

Poudel, B. N., Paudel, K. P., Timilsina, G., \& Zilberman, D. (2012). Providing Numbers for a Food Versus Fuel Debate: An Analysis of a Future Biofuel Production Scenario. Applied Economic Perspectives and Policy, 34(4), 637-68. http://dx.doi.org/10.1093/aepp/pps039

Redfearn, D. D., Moore, K., J., Vogel, K. P., Waller, S. S., \& Mitchell, R. B. (1997). Canopy Architecture and Morphology of Switchgrass Populations Differing in Forage Yield. Agronomy Journal, 89, 262-269. http://dx.doi.org/10.2134/agronj1997.00021962008900020018x

Runge, C. F., \& Senauer, B. (2007). How Biofuels Could Starve the Poor. Foreign Affairs, 86(3), 41-53.

Schmer, M. R., Vogel, K. P., Mitchell, R. B., \& Perrin, R. K. (2008). Net Energy of Cellulosic Ethanol from Switchgrass. Proceedings of the National Academy of Sciences, 105(2), 464-469. http://dx.doi.org/10.1073/pnas.0704767105

Secchi, S., \& Babcock, B. A. (2007). Impact of High Crop Prices on Environmental Quality: A Case of Iowa and the Conservation Reserve Program. Center for Agricultural and Rural Development, Iowa State University Ames, Iowa.

Taylor, R. D., \& Koo, W. W. (2010). Optimizing Ethanol Production in North Dakota. North Dakota State University, Department of Agribusiness and Applied Economics, Center for Agricultural Policy and Trade Studies.

Vogel, K. P. (1996). Energy Production from Forages (or American Agriculture-Back to the Future). Journal of Soil and Water Conservation, 51(2), 137-139.

Walsh, M. E., De La Torre Ugarte, D. G., Shapouri, H., \& Slinsky, S. P. (2003). Bioenergy Crop Production in the United States: Potential Quantities, Land Use Changes, and Economic Impacts on the Agricultural

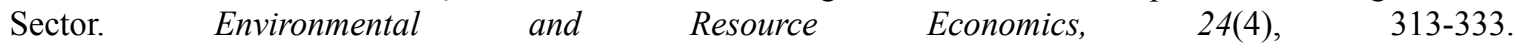
http://dx.doi.org/10.1023/A:1023625519092

Williams, J. R., \& Singh, V. P. (1995). The EPIC Model. Computer Models of Watershed Hydrology, 909-1000.

Woolsey, E. (1992). Switchgrass-Back to the Future. Paper presented at Energy Crops Forum, Oak Ridge National Laboratory, Spring.

\section{Notes}

Note 1. For a general discussion of the approach used here to model crop production, see McCarl (1982), and Chen and Önal (2012).

Note 2. With the large round baling system of harvest assumed here, when stover is collected at a lower rate per hectare, the raking operation must be completed over a larger area for a given quantity of stover, resulting in a somewhat greater harvest cost per ton.

\section{Copyrights}

Copyright for this article is retained by the author(s), with first publication rights granted to the journal.

This is an open-access article distributed under the terms and conditions of the Creative Commons Attribution license (http://creativecommons.org/licenses/by/3.0/). 